\title{
Archaeometric studies on early medieval silver jewellery from Central and Eastern Europe
}

\author{
Ewelina Miśta-Jakubowska ${ }^{1}$ - Renata Czech Błońska ${ }^{2}$ - Władysław Duczko ${ }^{2}$ • Aneta M. Gójska ${ }^{1}$ Paweł Kalbarczyk ${ }^{3}$. \\ Grzegorz Żabiński $^{4} \cdot$ Krystian Trela $^{1}$
}

Received: 9 November 2018 / Accepted: 2 September 2019 / Published online: 22 October 2019

(C) The Author(s) 2019

\begin{abstract}
Scanning electron microscopy with X-ray microanalyses (SEM-EDX) was used for a technological study of silver jewellery from three hoards found in Poland. The assemblage consists of 26 artefacts from the period of formation of the first Polish state ( 900 $1039 \mathrm{AD})$ and can be divided into three groups: West Slavic, post-Moravian and Scandinavian. Research results provide information concerning techniques used for granulation ornament and the provenance of raw silver. Elemental composition changes are manifested mainly by different $\mathrm{Cu}$ contents. A higher $\mathrm{Cu}$ content was found in solder. The higher $\mathrm{Cu}$ content in relation to the morphology of the joining region with visibly spilled granulation demonstrates that the West Slavic beads were produced with the use of metallic soldering. On the other hand, other studied jewelleries are characterised by $\mathrm{Cu}, \mathrm{Sn}, \mathrm{Sb}$ and $\mathrm{Zn}$ enrichments in oxidised soldering regions, which implies that they were manufactured with the use of non-metallic soldering. In addition, studies on the provenance of the raw material were made based on the analysis of lead isotopic ratios. For this purpose, laser ablation inductively coupled plasma mass spectrometry (LA-ICP-MS) was used, and the obtained lead isotopic ratios were processed using linear discriminant analysis (LDA). The isotope study demonstrates that all examined artefacts were made using re-melted metal from multiple sources. The most probable sources of silver were ores from Uzbekistan, Afghanistan and Freiberg (Germany).
\end{abstract}

Keywords SEM-EDX $\cdot$ LA-ICP-MS $\cdot$ Lead isotope ratios $\cdot$ Medieval jewellery $\cdot$ Silver hoards

\section{Introduction}

The aim of this paper is to discuss the results of recent research conducted on female ornaments from early medieval hoards in

Electronic supplementary material The online version of this article (https://doi.org/10.1007/s12520-019-00935-z) contains supplementary material, which is available to authorized users.

Ewelina Miśta-Jakubowska

Ewelina.Mista@ncbj.gov.pl

1 National Centre for Nuclear Research, A. Sołtana 7, 05-400 Otwock, Poland

2 Institute of Archaeology and Ethnology, Polish Academy of Sciences, Al. Solidarności 105, 00-140 Warsaw, Poland

3 Institute of Nuclear Chemistry and Technology, Dorodna 16, 03-195 Warsaw, Poland

4 Institute of History, Jan Długosz University in Częstochowa, Al. Armii Krajowej 36a, 42-200 Częstochowa, Poland
Poland (Dekówna 1974; Zoll-Adamikowa et al. 1999). Assemblages consisting of coins and other kinds of silver artefacts are important historical source materials from which it is possible to obtain data about economic, political and social conditions of people who were depositing silver. These issues are crucial for understanding the relations between early states in Central Europe, mainly between the first Polish state created by the Piast Dynasty, the Czech state and Scandinavian countries. The custom of deposition of silver and gold artefacts in the form of hoards was of Scandinavian origin and went into use in Piast Poland, but not in the Czech lands ruled by the Přemyslid Dynasty. The hoards, consisting of coins and ornaments, usually hacked into pieces, appear in the realm of the Piasts for the first time in the mid-tenth century, and their number gradually increases until the custom of hoard deposition disappears in the beginnings of the twelfth century (Jakimowicz 1933; Kostrzewski 1962). The ornaments from these hoards are covered with granulation, which was a decoration with ancient traditions (see, e.g. Duczko 1985 Eilbracht 1999; Pliny 1929; Theophilus 1979; Ogden 1982). Granulation was a favourite 
ornamentation technique among craftsmen working for social elites in the first state of the West Slavs, that is, Great Moravia, in the ninth century AD. The origins of ornaments are to be searched in the traditions of Late Roman Art which survived in the Byzantine Empire. Moravian ornaments, which are known only from burials, are of very high quality and represent a special phenomenon in early medieval European art (Čáp et al. 2011; Galuška 2013). After the destruction of the Moravian state in the early tenth century by the Hungarians, Moravian goldsmiths moved in two directions: westward to the Czech state, and eastward to Kievan Rus, created and ruled by the Scandinavians. Each group of these craftsmen created their own repertoire of types characteristic only for them. In the hoards found in the territory of the Piasts, there is a prevalence of ornaments typical for the Czech art, while ornaments of the eastern group are known from hoards deposited by the Rus, i.e. the Scandinavians living in Eastern Europe (Ukraine, Belarus and the European part of the Russian Federation). In the eastern hoards, post-Great Moravian ornaments were mixed with typical Norse jewellery, in which the techniques of filigree and granulation were also employed. Post-Great Moravian ornaments hold a special place in the European history of art, because of their own unique nature. As all jewellery, also those had religious and social functions (Duczko 2015, 2016, 2018). A few experimental technological studies were done (Thouvenin 1971, 1973; Baines 2005) however, they did not cover physico-chemical properties of jewellery of such type. Published results of contemporary studies on ornaments made with the use of granulation and filigree techniques are mainly focused on gold artefacts (e.g. Scrivano et al. 2013, 2017a, b; Ontalba Salamanca et al. 1998; Šmit et al. 2000, Šmit and Šemrov 2006).

A recent study by Ashkenazi et al. $(2017,2018)$ concerns results of research on silver treasures whose chronology strongly precedes the finds discussed in this article. In recent years, Czech researchers have commenced to fill this gap. What can be mentioned here is a series of archaeological experiments on the technology of manufacture of early medieval ornaments from Great Moravia, with a special focus on filigree and granulation (Čáp et al. 2011). Another important work deals with the composition of metal, construction and technology of goldsmith decorations discovered at the "Lumbe Garden" cemetery at Prague Castle (Ottenwelter et al. 2014). Ornament analyses were carried out by scanning electron microscopy using X-ray dispersion spectrometry. Yet another valuable study is a monograph with a detailed discussion on finds from Břeclav - Pohansko VII, including scanning electron microscopy of Great Moravian jewellery from the Pohansko site (Macháček et al. 2016).

However, the early appearance of Czech ornaments in Europe did not attract enough attention from researchers. W. Duczko studied Danish Viking ornaments, including Slavic artefacts. His first works were published in the 1970s and 1980s (research on finds from Birka in Sweden) and did not contain detailed analyses of physico-chemical traits of discussed finds (Duczko 1972, 1984, 1985, 1986). This issue, on a larger scale, is currently being researched by the authors as part of two grants in collaboration with the University of Stockholm and the National Museum in Stockholm.

\section{Material and methods}

\section{Archaeological material}

This paper discusses the results of research on 26 ornaments from three early medieval silver hoards discovered in Słuszków, Rajsków and Stojkowo in Poland (see Fig. 1).

The hoard from Słuszków (Kalisz District, Poland) is one of the largest ones of such kind in Poland (see Fig. 2). It was discovered in 1935 during land adjustment. Today, the hoard is in the collection of the District Museum of the Kalisz Region. The assemblage contains 13,061 finds, most of which being cross denars. The latest issues come from the end of the eleventh and the beginning of the twelfth century. The most numerous group in the hoard consists of cross denars of types I, II, IV, V, VI, VII and VIII. It includes 12,829 items, which is over $98 \%$ of artefacts in the assemblage. In addition, the Słuszków hoard also contains 32 granulated silver beads decorated with filigree (25 items with bosses, 4 oval ones and 3 small fragments of silver sheet with traces of granulation), 7 silver ingots and 71 foreign coins: Arabic, English, Danish, German, Czech and Hungarian, mostly preserved in fragments. However, the most spectacular group in the hoard are Palatine Sieciech's denars: 120 items with a cross pattée and $1+2$ with a monogram. It is the largest known assemblage of coins of this magnate.

The second of the examined hoards was accidentally discovered in 1992, when a residential building in the KaliszRajsków quarter was extended (see Fig. 3). Part of the hoard is kept in the Kalisz Museum and it includes 636 finds with a total weight of $281.2 \mathrm{~g}$. In this part of the hoard, 146 entirely preserved oriental coins and their fragments (a fragment of an Arab-Sasanian drachma from the end of the seventh century, and dirhams dated to the period between the end of the seventh and the end of the tenth century) were distinguished. Furthermore, German denars and their fragments, including the earliest type I cross denars, Czech and Scandinavian coins, as well as issues of Bolesław Chrobry (type CNP 47) from the initial period of this ruler's reign were present in the assemblage. There are 490 fragments of ornaments in the hoard, of which 16 specimens were selected for archaeometric research.

The third early medieval silver hoard discussed in this paper was discovered in 1926 in a village of Stojkowo (Fig. 4), $10 \mathrm{~km}$ to the east of Kołobrzeg (Kolberg) and is deposited now in the National Museum in Warsaw. Only a part of it weighting about $740 \mathrm{~g}$ has survived, while the rest weighting 


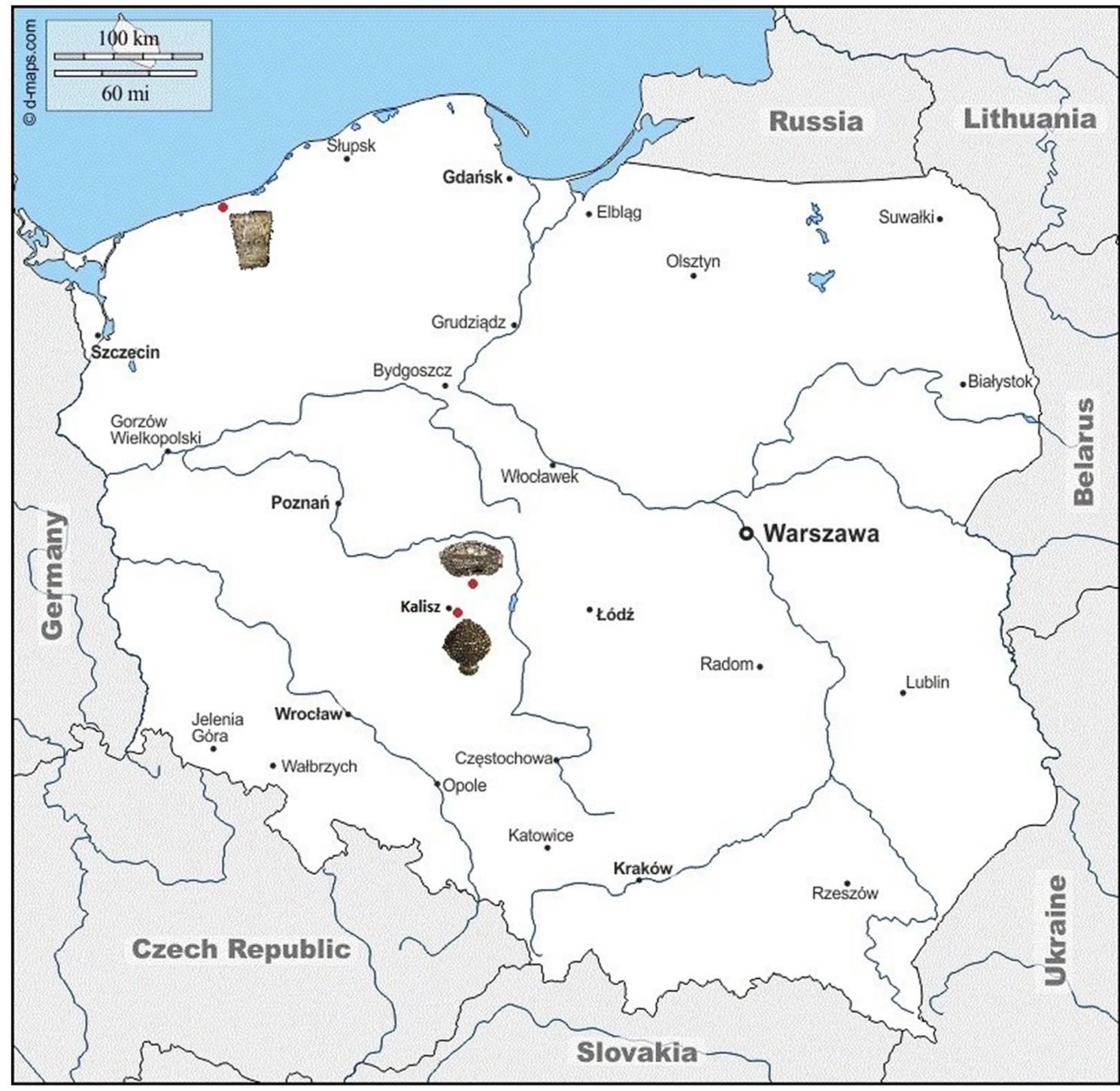

Places of finding the early medieval treasures described in the text, marked on the map of contemporary Poland.

- RAJSKów HOARD

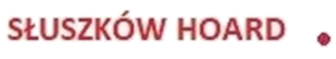

STOJKOWO HOARD

Fig. 1 Map of finds of the silver hoards discussed in this paper

about $400 \mathrm{~g}$ and a covered clay vessel in which the hoard was buried were lost during the Second World War. The preserved part consists of 102 coins (chiefly from German mints and 28 cross denars of types I, II, III, V, VI and VII), 9 lumps of cast silver or their fragments, 39 fragments of silver bars and silver sheets, 159 fragments of silver sticks and wire and 152 various silver ornaments (parts of rings, temple-ring pendants, silver beads, chains, necklaces and buckles), mostly hacked and broken. Probably about 400 coins (mostly dirhams) and some other artefacts, among them a few fragments of silver bars, were lost. Information concerning this lost part of the hoard was obtained from literature. However, this data is far from adequate and precise (Kiersnowska and Kiersnowski 1955).

\section{Structural and elemental composition analyses}

Before laboratory analyses, the artefacts were cleaned in AVEL Silver Cleaner solution (http://www.avel.com/avel-33/ produit/293-silverware-avel-33.html, accessed on 2 August 2017), and then they were bathed in acetone and air dried in order to remove conservation layers. The conservation of the jewelleries included mechanical cleaning, application of 5\% disodium edetate solution (Ślesiński 1995) and covering the surface with Paraloid B-72 acrylic resin (Costa 2001). The 
Fig. 2 Silver beads from the early medieval hoard from Słuszków: West Slavic group. Photo: M. Osiadacz

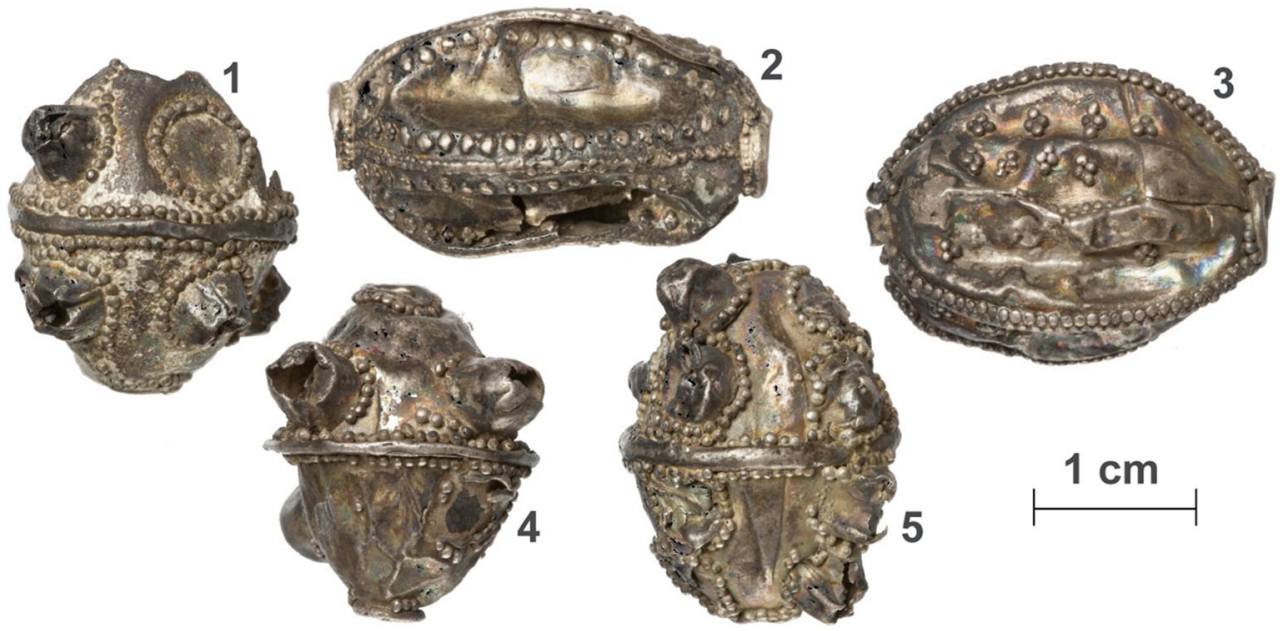

state of preservation of the finds was good and no corrosion was observed.

SEM-EDX (scanning electron microscopy with X-ray microanalysis) was the main technique which was used for the study of technological changes in surfaces of the discussed ornaments. This was due to the surface interaction of the excitation electron beam and a possibility of EDX signal registration from near-surface layers (Gójska et al. 2019) in the region of soldering occurring up to about $30 \mu \mathrm{m}$ from the surface (Koláŕová et al. 2014). SEM-EDX analysis, described in detail in Goldstein et al. (2007), is a popular non-destructive technique used in studies of archaeological finds (e.g. Scrivano et al. 2017a, b; Ontalba Salamanca et al. 1998; Ashkenazi et al. 2017, 2018; Linke and Schreiner 2000, Linke et al. 2003, 2004; Ingo et al. 2004; Miśta et al. 2017; Gójska and Miśta 2016). Twenty-six artefacts were tested altogether.
The SEM-EDX study provided information about morphological changes and allowed for a determination of the quantitative elemental composition in the micro-scale, taking specifications of the solder region, base surface and granule compositions into account. The granules and surface where they were attached by soldering are referred to as the base surface in the further part of this paper. This was due to their similar elemental composition. For each technological area of a given artefact, at least $n=3$ measurements were carried out. The SEM-EDX analysis was done using a Carl Zeiss EVO MA10 Scanning Electron Microscope equipped with an EDAX X-Flash Detector 5010 with a $123-\mathrm{eV}$ spectra resolution (Zeiss. Poland; www.zeiss.com) and provided with a Bruker Quantax 200 Esprit 1.9 system for analyses of EDX spectra. The image analysis was carried out using a secondary electron detector (SE) with a resolution up to $2.0 \mathrm{~nm}$. Other parameters were the following: accelerating voltage $20 \mathrm{keV}$, a

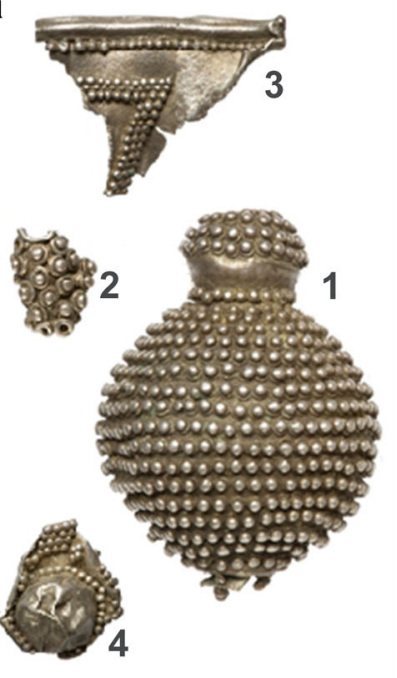

b
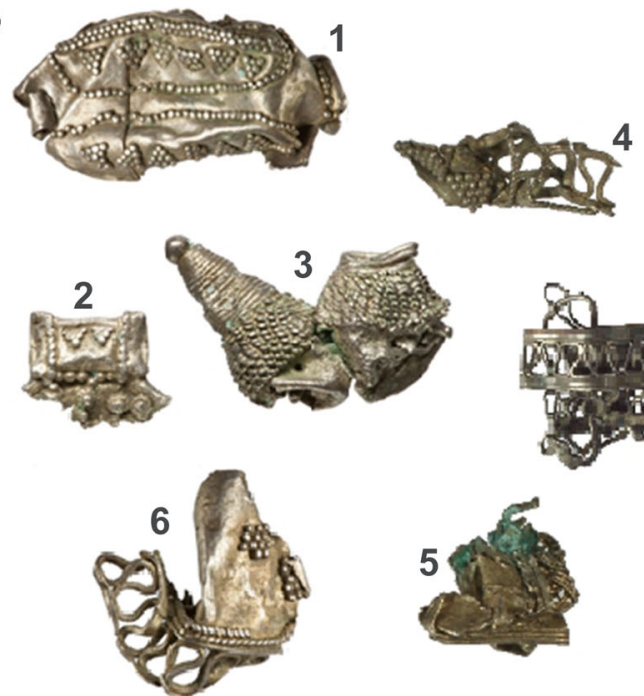

C
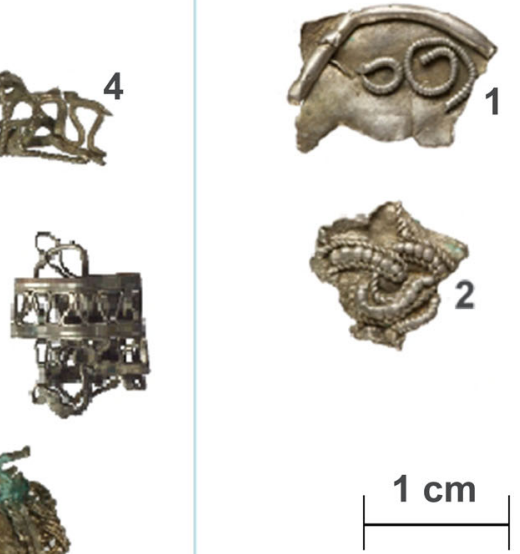

Fig. 3 Silver ornaments from the early medieval hoard from Rajsków: a post-Moravian group; b West Slavic group; c Scandinavian group. Photo: M. Osiadacz 
Fig. 4 Silver ornaments from the early medieval hoard from Stojkowo: Scandinavian group. Photo: M. Osiadacz

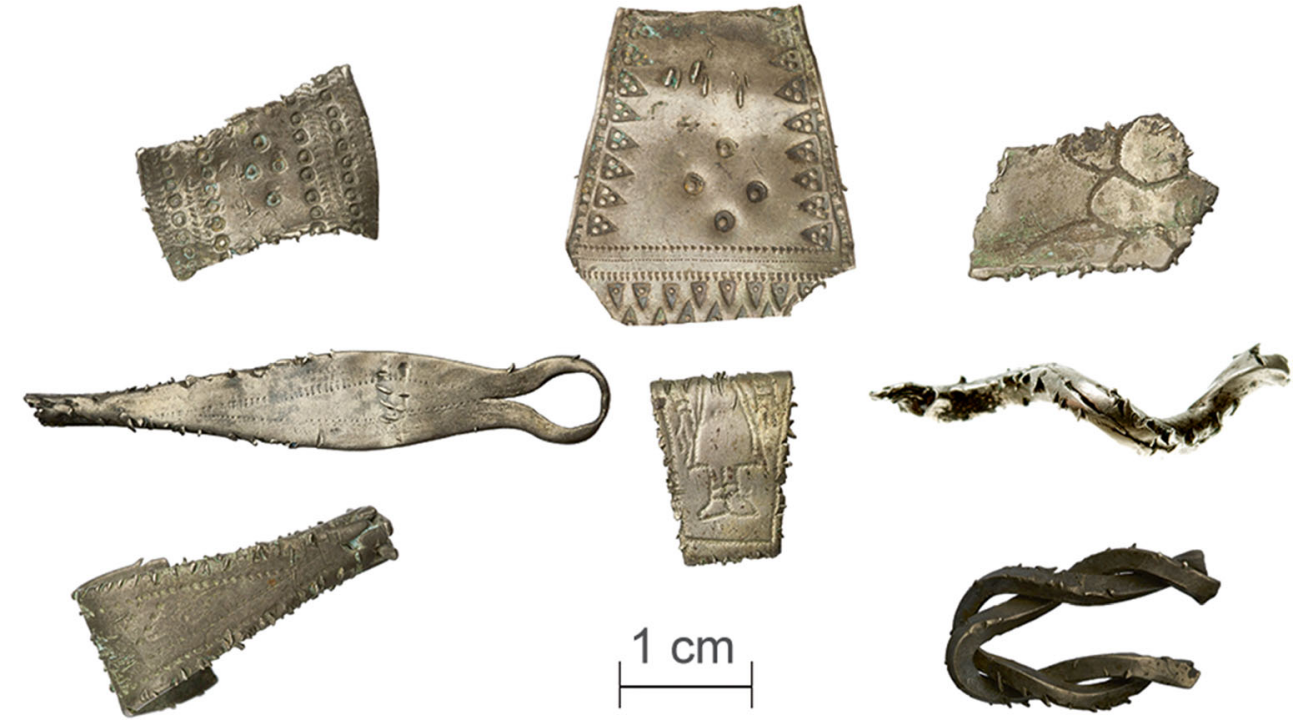

measurement time $120 \mathrm{~s}$ and LLD $=0.1 \mathrm{wt} \%$. The current and field magnification was adjusted to the type of morphology of each studied surface. The quantitative analysis was done using the non-pattern method with an error $<3 \%$ for the main elements and $<20 \%$ for traces below $1 \mathrm{wt} \%$. Standard reference materials which were used for EDX result authentication were $\mathrm{Ag}$ and $\mathrm{Cu}$ alloy mixtures in all $\mathrm{Ag} / \mathrm{Cu} \%$ range (ESPI metals).

\section{Lead isotope analyses}

Furthermore, an ore provenance study was carried out based on the results obtained for 20 ornaments. The micro-invasive LA-ICP-MS was carried out with an ELAN 9000 Inductively Coupled Plasma Mass Spectrometer (Perkin Elmer SCIEX, Canada: www.perkinelmer.com) equipped with an LSX$200^{+}$laser ablation system (CETAX, USA: www.cetax. com). The LSX $-200^{+}$combines a stable environmentally selected 266-nm UV laser (Nd-YAG, solid state, Q-switches) with a high sampling efficiency, variable 1 to $20 \mathrm{~Hz}$ pulse repetition rate and maximum energy up to $6 \mathrm{~mJ} / \mathrm{pulse}$. The applicability of this technique in archaeological provenance analyses is briefly discussed by several authors (e.g. Baker et al. 2006; Budd et al. 1995; Hirata 1996; Stos-Gale \& Gale 2009). The NIST 981 reference standard material was used for quantitative determination of lead isotope concentrations $(0$. 059042, 0.91464 and 2.1681 for $\mathrm{Pb}^{204 / 206}, \mathrm{~Pb}^{207 / 206}$ and $\mathrm{Pb}^{208 / 206}$ with relative standard deviation below $0.1 \%$ ). Measured median values $(n=78)$ with relative standard deviation are $0.0610 \pm 1.08,0.0915 \pm 1.02$ and $2.1720 \pm 1.16 \%$ for $\mathrm{Pb}^{204 / 206}, \mathrm{~Pb}^{207 / 206}$ and $\mathrm{Pb}^{208 / 206}$, respectively. For each artefact, $n=40$ measurements were carried out with $\mathrm{SD}:<6 \%$ for $\mathrm{Pb}^{206} / \mathrm{Pb}^{207},<7 \%$ for $\mathrm{Pb}^{208} / \mathrm{Pb}^{206}$ and $<5 \%$ for $\mathrm{Pb}^{207 / 204}$.

The obtained results of the elemental composition and lead isotope study were processed using principal component analyses (PCA) and linear discriminant analysis (LDA). A kernel density estimator (KDE) model was used to obtain a 3D model of lead isotopic ratio distribution in artefacts (Kulczycki 2005; Baxter 2003, 2016; Everitt and Hothorn 2011; Everitt et al. 2011).

\section{Results}

\section{SEM-EDX analysis of technological changes in the surface of the ornaments}

A series of 26 silver ornaments - 18 made in filigree and granulation techniques (in one find from the Rajsków hoard - the artefact without no. in Fig. 3-the soldering area was not identified by the SEM-EDX analysis) and 8 without such decoration (the finds from the Stojkowo hoards, see in Fig. 4)-were examined. These artefacts belong to the West Slavic (12 finds - 5 from Słuszków, see Fig. 3, and 7 from Rajsków, see in Fig. 3b), post-Moravian (4 finds from Rajsków, see Fig. 3a) and Scandinavian (10 finds -2 from Rajsków, see Fig. 3c, and 8 from Stojkowo, see Fig. 4) groups. The technological groups were isolated based on visual characterisation according to Duczko (1985).

The surface morphology of all precious metal artefacts was studied by SEM-SE. In the case of ornaments with granulation, three technological areas were identified: 1-base surface made of silver alloy; 2 - joining zone located between the surface and the decoration; and 3-ornamentation on the base silver alloy, e.g. granulation and twisted wire.

Furthermore, on the basis of morphological differences in the ornamentation zone which were identified by SEM observations, three types of joining were found: (i) spilled granulation ornaments, (ii) non-oxidised spherical granules and (iii) oxidised soldering area with spherical granules. 
All the analysed beads from Słuszków display similar characteristics of the soldering area with the lack of extensive oxidised structure in the soldering region. Such structures associated with two different solder types are presented in Figs. 5 and 6. Figure 5 (surface of find 2 from Fig. 2) offers examples of SEM-SE images recorded for the first type of the joining structure. This variety is characterised by granules which are smoothly embedded in the surface. The size of these granules is about $300 \mu \mathrm{m}$ (see Fig. 5). Moreover, the shape of the granules is fuzzy and a significant merging with the solder structure can be seen. The ornament is spilled on the surface. Furthermore, in Fig. 6, one can see granules separated from the solder layer which is characterised by the lack of extensive oxide structures. The size of these granules is about $400 \mu \mathrm{m}$ (see Fig. 6).

Different technological types of joining areas were observed in the case of ornaments from the Rajsków hoard. Figures 7 and 8 offer SEM-SE images of a micro-region with the granulation ornament. Cloudy shapes of joining structures between granules are visible with the size of the granules from 300 (see Fig. 8) to $400 \mu \mathrm{m}$ (see Fig. 7).

Based on the SEM images, it can be said that the spilled ornament (as discussed below) with relatively small size of the granules and the lack of oxide structures indicates the use of metallic soldering (Ottenwelter et al. 2014; Macháček et al. 2016; Ferro et al. 2009) in the case of the beads from the Stuszków hoard. The presence of oxide structure in the area of tiny granule assemblage in the finds from Rajsków could be a chemical soldering effect (Čáp et al. 2011; Duczko 1985). The elemental composition study results confirm the above assumption, as described below.

Furthermore, the EDX elemental composition of ornaments allowed to distinguish technological micro-areas within three archaeological types. Ag, Cu, Bi, Pb, Zn, Sn, Au, Hg, Sb and $\mathrm{O}$ concentrations above $0.1 \mathrm{wt} \%$ were identified as a normalised value. The results are presented in Table 1 . The West Slavic and Scandinavian types were divided into two groups according to visual traits, i.e. beads from Słuszków have a different soldering area as shown by SEM analyses (see Figs. 5 and 6). On the other hand, the finds from the
Stojkowo hoard resemble Scandinavian-type artefacts without granulation (see Fig. 4).

What is important while analysing the results is that the elemental composition determined for each technological part is only approximate due to a considerable blur of the elements' distribution on the surface micro-regions. This results from the fact that these ornaments were processed at high temperatures (Untracht 1985; Wolters 1983). In our study, the division into the base surface and the soldering area was confirmed by the linear discriminant analysis. Table 2 presents the results of LDA correct allocation for two selected (based on elemental composition in Table 1) technological areas. The greatest spill of solder over the surface is visible in the WSS type. Based on the results presented in Table 2, the division shown in Table 1 seems to be appropriate.

As it can be seen in Table 1, the soldering area of the West Slavic artefacts from Rajsków is the most oxidised (O up to $51.4 \mathrm{wt} \%)$ with the highest concentration of copper $(\mathrm{Cu})$ up to $57.3 \mathrm{wt} \%$ and high tin ( $\mathrm{Sn}$ ) and antimony (Sb) contents. The solder in the post-Moravian jewelleries (see Figs. 7 and 8) is similar with regard to the content of $\mathrm{O}$, while it has a lower $\mathrm{Cu}$ content (up to $27.8 \%$ ) and slightly higher Sn (up to $24.7 \mathrm{wt} \%$ ), $\mathrm{Pb}$ (up to $7.0 \mathrm{wt} \%$ ) and $\mathrm{Sb}$ (up to $19.5 \mathrm{wt} \%$ ) concentrations.

Concerning the solder type, all five beads from Słuszków are characterised by the lack of very oxidised structure (see Figs. 5 and 6) with the $O$ content in the range from 3.3 to $22.6 \mathrm{wt} \%$. The $\mathrm{Cu}, \mathrm{Sn}$ and $\mathrm{Zn}$ contents are also low, as compared with other types of jewelleries (see Table 1) with slight $\mathrm{Pb}$ and $\mathrm{Cu}$ enrichment.

The soldering area of the Scandinavian jewelleries from Rajsków is enriched in $\mathrm{Cu}, \mathrm{Sn}, \mathrm{Sb}, \mathrm{Pb}$ and $\mathrm{O}$ with regard to their base surface. The base surface of the finds without granulation from the Stojkowo hoard is different from other types of the base surface (see Fig. 9a). It is enriched in $\mathrm{Cu}$ and $\mathrm{Pb}$.

Generally, the elemental composition differences determined for all the types of jewelleries are presented graphically below, both as a difference in the content of elements in the soldering areas (see Fig. 9b) and raw silver (see Fig. 9a) which was used to produce the base surface and ornaments. In the diagrams below, all EDX measurements were taken into account.
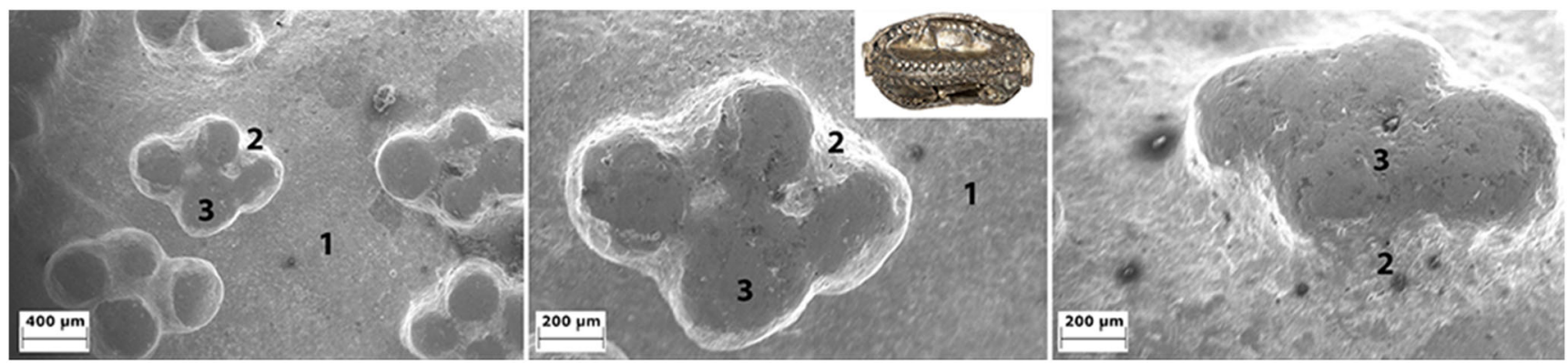

Fig. 5 SEM-SE images of the surface of the silver bead from Słuszków (Fig. 2: no. 2) characterised by spilled granulation ornament. The technological parts are as follows: 1 - base surface, 2 - soldering area and 3 - granules as part of the granulation ornament 

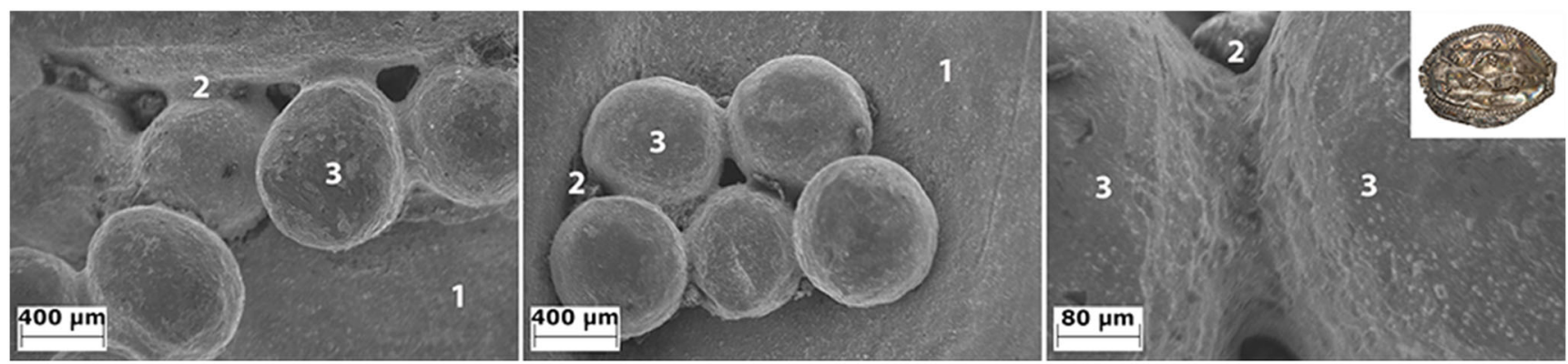

Fig. 6 SEM-SE images of the surface of the silver bead from the Słuszków hoard (Fig. 2: no. 3), find 12683. Regular spherical granules without extensive oxidised solder area can be seen. Designations (1-3) as in Fig. 5

Figure 9 shows the results of the elemental composition analysis presented as a LDA diagram (Baxter 2016, 2003; Everitt and Hothorn 2011). The LDA confusion matrix can be found in Table 3.

As it can be seen in Fig. 9 and Table 3, the base surface regions in all types of jewelleries with granulations are similar concerning their elemental composition. A better separation $(61 \%)$ is observed for the artefacts without granulations from the Stojkowo hoard. Furthermore, in the case of the soldering area, a better allocation to the group can be seen for WSS (72\%), WSR (54\%) and Sc.R (50\%). The soldering regions of PM jewelleries are similar to all other types and the allocation to the predicted group is $30 \%$. Figures 10, 12, 14 and 15 illustrate a graphical distribution of variability of $\mathrm{Ag}, \mathrm{Cu}, \mathrm{Bi}$, $\mathrm{Au}, \mathrm{Pb}, \mathrm{Hg}, \mathrm{Sn}, \mathrm{Zn}, \mathrm{Sb}$ and $\mathrm{O}$ concentrations. In the diagrams, there are marked areas (respectively, I-II, a-c) with composition anomaly in the groups in question. Figures 10b, 12b, 14b and $15 \mathrm{~b}$ (as a fragment of Fig. 9b) present LDA separation of the soldering area for each artefact within archaeological groups. Numerical designations of the finds are explained in Figs. 2 and 3. Moreover, the a) parts of Figs. 10, 12, 14 and 15 contain PCA correlation-type diagrams presenting the results of the elemental composition analyses of the soldering region and the base surface in each technological group.

Generally, as it is shown in the PCA diagrams from panels a of Figs. 10, 12, 14 and 15, the division into the base surface and the soldering region within a given archaeological group based on the elemental composition is justified (which is in accordance with what is offered in Table 2). The main classification error occurs only in Fig. 15: point II. In all PCA diagrams, the $\mathrm{Ag}$ content is correlated with the base surface, while $\mathrm{Cu}, \mathrm{Sn}, \mathrm{Zn}, \mathrm{Sb}$ and $\mathrm{Bi}$ are related to the soldering region. However, as reported by Kolářová et al. (2014), the registered EDX signal gives information about the base surface contaminated by solder components (Wolters 1983).

In Fig. 10, in the soldering area, there are two notable anomalies with higher $\mathrm{Cu}$ (up to $29.5 \mathrm{wt} \%$ ), Sn (up to $8.8 \mathrm{wt} \%$ ), $\mathrm{Sb}$ (up to $4.6 \mathrm{wt} \%$ ) and $\mathrm{O}$ (up to $56.5 \mathrm{wt} \%$ ) contents. They concern find no. 2 in Fig. 3c. The SEM-SE images of the soldering region of this pendant can be seen in Fig. 11. In turn, the composition of this joining area is slightly similar to what occurs in the WSR and PM type (see Fig. 9b).

The largest anomalies within the soldering area are present in the PM group, which is also evidenced by the LDA results presented in Table 3 (only 30\% of correct allocations). There are observed anomalies in the concentration of low-melted elements such $\mathrm{Pb}, \mathrm{Sn}, \mathrm{Zn}, \mathrm{Sb}, \mathrm{Bi}$ and $\mathrm{Cu}$. These anomalies can be seen in the case of finds nos. 2 (no a, b, I in Fig. 12) and 4 (no c, II, III in Fig. 12) from Fig. 3a. The first one is characterised by a much higher content of $\mathrm{Sb}$ (up to $19.5 \mathrm{wt} \%$ ), $\mathrm{Sn}$ (up to $24.7 \mathrm{wt} \%$ ) and $\mathrm{Cu}$ (up to $27.8 \mathrm{wt} \%$ ) with higher $\mathrm{Pb}, \mathrm{Zn}$ and $\mathrm{O}$ concentrations. The other one is characterised by the oxidised soldering region (up to $50.4 \mathrm{wt} \%$ ) with higher $\mathrm{Cu}$ and $\mathrm{Sn}$ concentrations, as it can be seen in Fig. 7. In the PCA diagram (Fig. 12a), there are strong $\mathrm{Sn}-\mathrm{Sb}$ and $\mathrm{Zn}-\mathrm{Cu}$ correlations, which means that these
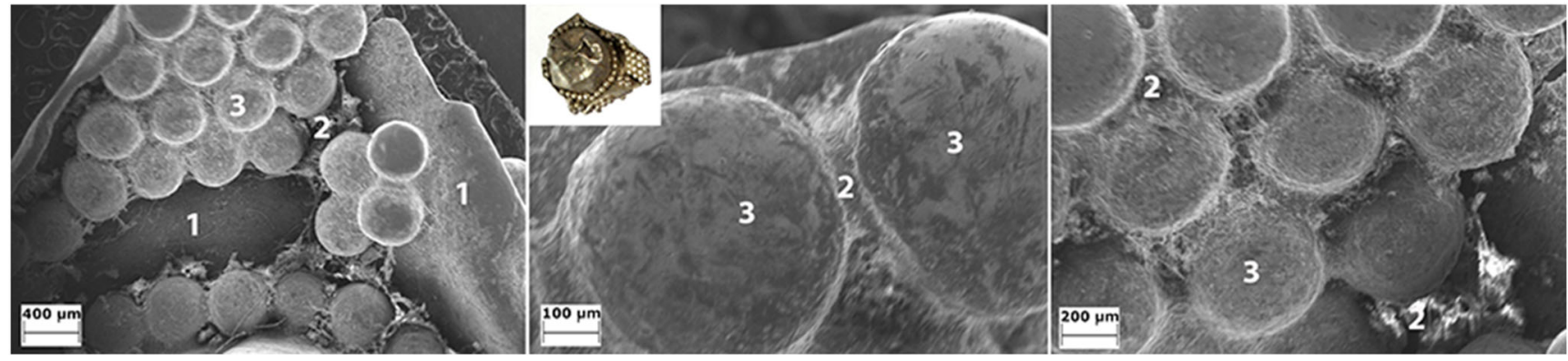

Fig. 7 SEM-SE images of the surface of the silver bead from the Rajsków hoard (see Fig. 2: no. 4). An oxidised solder area and regular spherical granules can be seen. Designations (1-3) as in Fig. 5 

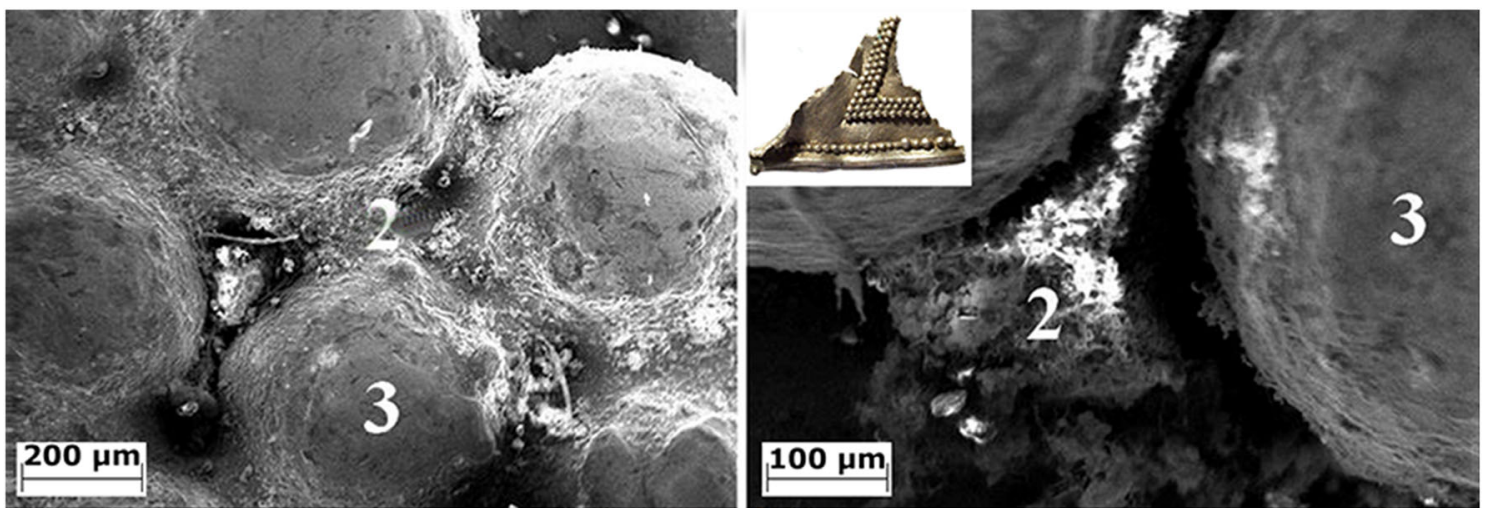

Fig. 8 SEM-SE images of the granulation area of the silver bead surface from the Rajsków hoard (see Fig. 2: no. 1). There are oxidised soldering structures (2) located in the space between granules (3)

components could be added in this substrate correlation to the joining mixture. Figure 13 shows the soldering region of the abovementioned pendant marked as no. 2 in Fig. 3 a.

The raspberry pendant presented below is an example of an ornament characterised by higher contents of low-melted elements in the oxidised solder areas. Moreover, a higher percentage of gold ( $\mathrm{Au}$ ) up to $2.7 \mathrm{wt} \%$ and mercury ( $\mathrm{Hg}$ ) up to $2.4 \mathrm{wt} \%$ was recorded in the entire artefact. Generally, for the entire assemblage from the Rajsków hoard, the mercury enrichment (up to $4.0 \mathrm{wt} \%$ ) is mainly observed for the base surface, but in some cases, it is also related to the soldering region. For five ornament fragments - a bead with a bump, WS type (see Fig. 3b: no. 2, see Fig. 14 below point I); a starry earring with filigree (Fig. 3b: no. 6, WS type); an earring (PM type); a round pendant (Sc type); and a raspberry pendant (PM type) - a slightly increased content of gold and mercury was detected in the micro-region.

The soldering region of the WSR group is characterised by $54 \%$ allocation to the correct group with a high (31\%) allocation to the PM group (see Table 3). The two anomalies are observed for two artefacts: nos. 2 (see point I in Fig. 14) and 3 (see point a in Fig. 14) from Fig. 3b. Generally, the entire soldering area of the WSR group is oxidised and characterised by the positively correlated $\mathrm{Sn}, \mathrm{Cu}$ and $\mathrm{Sb}$ contents, while in the PM group there is the oxidised soldering area with correlated $\mathrm{Cu}-\mathrm{Zn}$ and $\mathrm{Sb}-\mathrm{Sn}$ contents (see Fig. 12). Moreover, the

Table 1 SEM-EDX analysis results

\begin{tabular}{|c|c|c|c|c|c|c|c|c|c|c|c|c|c|}
\hline \multirow[t]{2}{*}{ Arch. type } & \multirow[t]{2}{*}{ Hoard } & \multirow[t]{2}{*}{ Tech. area } & & \multicolumn{10}{|l|}{$(\mathrm{wt} \%)$} \\
\hline & & & & $\mathrm{Ag}$ & $\mathrm{Cu}$ & $\mathrm{Bi}$ & $\mathrm{Au}$ & $\mathrm{Pb}$ & $\mathrm{Hg}$ & $\mathrm{Sn}$ & $\mathrm{Zn}$ & $\mathrm{Sb}$ & $\mathrm{O}$ \\
\hline \multirow[t]{8}{*}{ West Slavic } & \multirow{4}{*}{$\begin{array}{l}\text { Słuszków (WSS), } \\
5 \text { obj. }\end{array}$} & \multirow[t]{2}{*}{ Base surface } & Av. $(n=37)$ & 87.8 & 3.4 & 0.7 & 0.7 & 0.7 & 0.7 & 0.1 & 0.1 & $<0.1$ & 6.0 \\
\hline & & & $\Delta$ & $72.6-95.6$ & $<9.5$ & $<3.4$ & $<4.7$ & $<3.4$ & $<3.1$ & $<1.1$ & $<1.0$ & $<0.1$ & $1.2-16.0$ \\
\hline & & \multirow[t]{2}{*}{ Soldering area } & Av. $(n=21)$ & 79.5 & 6.7 & 1.3 & 0.9 & 1.7 & 0.9 & 0.3 & 0.2 & 0.1 & 8.5 \\
\hline & & & $\Delta$ & $63.1-88.7$ & $2.4-11.0$ & $<5.0$ & $<4.2$ & $<6.3$ & $<2.8$ & $<1.7$ & $<0.9$ & $<0.9$ & $3.3-22.6$ \\
\hline & \multirow{4}{*}{$\begin{array}{l}\text { Rajsków (WSR), } \\
7 \text { obj. }\end{array}$} & \multirow[t]{2}{*}{ Base surface } & Av. $(n=42)$ & 88.8 & 3.9 & 0.4 & 0.6 & 0.5 & 0.5 & 0.3 & $<0.1$ & $<0.1$ & 4.8 \\
\hline & & & $\Delta$ & $69.3-95.7$ & $2.3-9.4$ & $<3.0$ & $<3.4$ & $<3.5$ & $<2.8$ & $<2.1$ & $<0.1$ & $<0.1$ & $<20.7$ \\
\hline & & \multirow[t]{2}{*}{ Soldering area } & Av. $(n=26)$ & 33.4 & 23.0 & 1.0 & 0.7 & 1.0 & 0.6 & 3.9 & 0.5 & 2.2 & 33.7 \\
\hline & & & $\Delta$ & $2.2-87.6$ & $3.4-57.3$ & $<9.5$ & $<6.2$ & $<6.6$ & $<3.8$ & $<18.6$ & $<2.3$ & $<13.1$ & $4.3-51.4$ \\
\hline \multirow[t]{4}{*}{ Post-Moravian } & \multirow{4}{*}{$\begin{array}{l}\text { Rajsków, (PM), } \\
4 \text { obj. }\end{array}$} & \multirow[t]{2}{*}{ Base surface } & Av. $(n=41)$ & 87.9 & 3.2 & 0.9 & 1.0 & 0.3 & 1.1 & 0.1 & 0.1 & $<0.1$ & 5.6 \\
\hline & & & $\Delta$ & $75.8-99.0$ & $0.5-6.0$ & $<4.0$ & $<3.2$ & $<2.8$ & $<4.0$ & $<1.4$ & $<0.7$ & $<0.1$ & $<18.4$ \\
\hline & & \multirow[t]{2}{*}{ Soldering area } & Av. $(n=30)$ & 50.6 & 12.7 & 1.1 & 1.2 & 1.7 & 0.9 & 4.9 & 0.5 & 2.3 & 24.2 \\
\hline & & & $\Delta$ & $4.9-75.7$ & $4.4-27.8$ & $<5.4$ & $<3.1$ & $<7.0$ & $<3.4$ & $<24.7$ & $<2.3$ & $<19.5$ & $9.3-50.4$ \\
\hline \multirow[t]{6}{*}{ Scandinavian } & \multirow{4}{*}{$\begin{array}{l}\text { Rajsków } \\
\quad \text { (Sc. R), } 2 \text { obj. }\end{array}$} & \multirow[t]{2}{*}{ Base surface } & Av. $(n=8)$ & 90.2 & 3.2 & 0.2 & 0.6 & 0.3 & 1.1 & 0.2 & 0.1 & $<0.1$ & 4.2 \\
\hline & & & $\Delta$ & $83.4-96.3$ & $1.4-6.1$ & $<1.5$ & $<3.4$ & $<1.6$ & $<2.2$ & $<0.7$ & $<0.6$ & $<0.1$ & $1.4-7.7$ \\
\hline & & \multirow[t]{2}{*}{ Soldering area } & Av. $(n=9)$ & 58.3 & 11.8 & 0.6 & 1.5 & 1.6 & 1.2 & 2.8 & 0.2 & 1.1 & 20.9 \\
\hline & & & $\Delta$ & $5.0-80.1$ & $4.6-29.5$ & $<3.5$ & $<4.9$ & $<4.8$ & $<2.7$ & $<8.8$ & $<1.1$ & $<4.6$ & $8.3-56.5$ \\
\hline & \multirow{2}{*}{$\begin{array}{l}\text { Stojkowo } \\
\quad \text { (Sc. St), } 7 \text { obj. }\end{array}$} & \multirow[t]{2}{*}{ Base surface } & Av. $(n=31)$ & 84.9 & 6.0 & 1.2 & 0.8 & 1.4 & 0.7 & $<0.1$ & 0.4 & $<0.1$ & 4.6 \\
\hline & & & $\Delta$ & $60.6-92.2$ & $2.8-17.3$ & $<3.1$ & $<2.3$ & $<3.5$ & $<2.7$ & $<0.6$ & $<1.3$ & $<0.1$ & $0.7-21.2$ \\
\hline
\end{tabular}

$n$ number of measurements, $\Delta$ range of composition variation for the technological area 
Table 2 Part of the LDA confusion matrix for the training sample showing correct allocation for the technological areas of the archaeological types (two training sets/technological group - base surface and soldering area; 10 variables: $\mathrm{Ag}, \mathrm{Cu}, \mathrm{Bi}, \mathrm{Au}, \mathrm{Pb}, \mathrm{Hg}, \mathrm{Sn}, \mathrm{Zn}$, $\mathrm{Sb}, \mathrm{O})$

\begin{tabular}{lcl}
\hline Correct allocation: $n(\%)$ & Base surface & Soldering area \\
\hline Sc.R & $6(75 \%)$ & $10(100 \%)$ \\
PM & $41(100 \%)$ & $25(83 \%)$ \\
WSS & $28(80 \%)$ & $14(67 \%)$ \\
WSR & $42(100 \%)$ & $22(85 \%)$ \\
\hline
\end{tabular}

WSS soldering region demonstrates a better $\mathrm{Pb}-\mathrm{Zn}$ correlation.

The soldering region of the WSS group is in $71 \%$ of cases allocated to the correct group. Only six measurement points are better assigned to other groups (see Table 3). This group is best distinguished in terms of the solder composition (see Fig. $9 \mathrm{~b})$. However, the distinction between base and soldering is the most disturbed (as shown in Table 2 and Fig. 15a), which is an effect of spilling of the solder over the surface (Wolters 1983). In Fig. 15, there are four protruding points in the group with different compositions. These compositions are related to two artefacts. Generally, in the WSS group, the soldering region demonstrates slight $\mathrm{Pb}$ and $\mathrm{Cu}$ enrichments with a lower oxidisation degree (Table 1, Figs. 5 and 6).

\section{Lead isotopic characteristics of the provenance of raw silver}

One of the most important questions concerning the investigated silver ornaments is the provenance of the raw material. It
Table 3 LDA confusion matrix for the training sample. Data obtained for the base surface and the soldering area of jewelleries groups

\begin{tabular}{|c|c|c|c|c|c|}
\hline $\begin{array}{l}\text { From/to } \\
n(\%)\end{array}$ & Sc.R & Sc.St & $\mathrm{PM}$ & WSS & WSR \\
\hline \multicolumn{6}{|c|}{ Base surface (as in Fig. 9a) } \\
\hline Sc.R & $2(25 \%)$ & $2(25 \%)$ & $2(25 \%)$ & $0(0 \%)$ & $2(25 \%)$ \\
\hline Sc.St & $2(7 \%)$ & $19(61 \%)$ & $3(10 \%)$ & $2(6 \%)$ & $5(16 \%)$ \\
\hline PM & $10(24 \%)$ & $0(0 \%)$ & $13(32 \%)$ & $10(25 \%)$ & $8(19 \%)$ \\
\hline WSS & $2(6 \%)$ & $5(14 \%)$ & $8(22 \%)$ & $12(33 \%)$ & $9(25 \%)$ \\
\hline WSR & $10(24 \%)$ & $5(12 \%)$ & $5(12 \%)$ & $9(21 \%)$ & $13(31 \%)$ \\
\hline \multicolumn{6}{|c|}{ Soldering area (as in Fig. 9b) } \\
\hline Sc.R & $5(50 \%)$ & - & $0(0 \%)$ & $3(30 \%)$ & $2(20 \%)$ \\
\hline PM & $7(23 \%)$ & - & $9(30 \%)$ & $6(20 \%)$ & $8(27 \%)$ \\
\hline WSS & $3(14 \%)$ & - & $2(9 \%)$ & $15(72 \%)$ & $1(5 \%)$ \\
\hline WSR & $1(4 \%)$ & - & $8(31 \%)$ & $3(11 \%)$ & $13(54 \%)$ \\
\hline
\end{tabular}

$n$ number of measurements

is important to know whether the silver comes from one or many different sources. It may be supposed that re-melting of earlier artefacts took place in Europe since the Migration Period (400-800 AD). Therefore, one can expect more than one value of individual isotopic ratios in one and the same artefact. Due to this, destructive analytical techniques, such as TIMS or ICP-MS (e.g. Cattin et al. 2009; Ettler et al. 2015), may introduce a considerable error to the interpretation of results. This is because these techniques yield an average result already in the course of sampling. In this paper, it is attempted at providing results of isotopic analyses taking into consideration changes of the so-called isotopic signature of the sample in the micro-scale. These changes may result from possible re-melting or heterogeneity of the raw material which
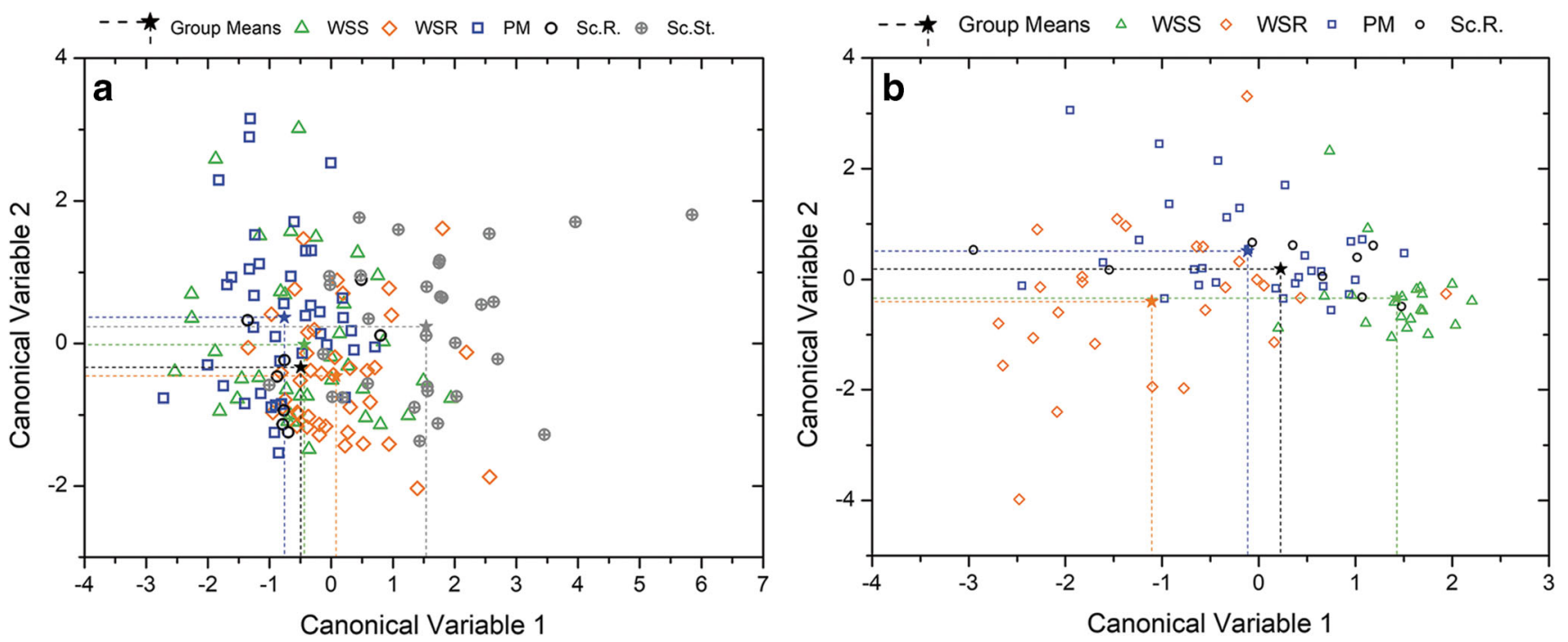

Fig. 9 LDA showing the variability of $\mathrm{Ag}, \mathrm{Cu}, \mathrm{Bi}, \mathrm{Au}, \mathrm{Pb}, \mathrm{Hg}$ and $\mathrm{O}$ contents in the base surface of the archaeological types and $\mathbf{b} \mathrm{Ag}, \mathrm{Cu}, \mathrm{Bi}, \mathrm{Au}, \mathrm{Pb}$, $\mathrm{Hg}, \mathrm{Sn}, \mathrm{Zn}, \mathrm{Sb}$ and $\mathrm{O}$ contents in the soldering area of the finds with granulations within archaeological types. Designations of the groups as in Table 1 

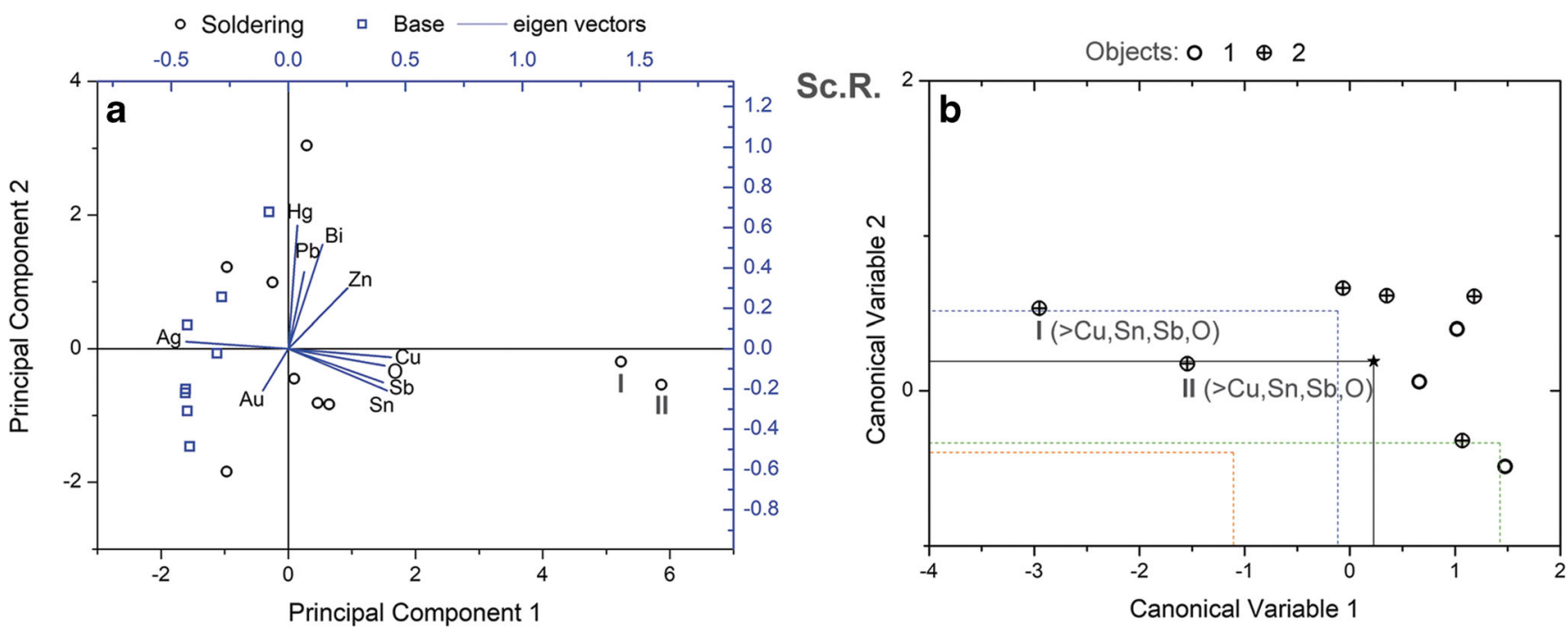

Fig. 10 Scandinavian-type finds with wires from the Rajsków hoard presented in Fig. 3c as nos. 1 and 2 (Sc.R type): a PCA results for the base surface and the soldering area and $\mathbf{b}$ LDA results for the soldering area of individual finds from the group (zoom of Fig. 9b)

was used. The isotopic analysis which is offered below was divided into two areas - an analysis within technological groups and a provenance analysis. In the latter case, geological data (as means) was taken from the available literature (Ettler et al. 2015; Merkel et al. 2013; Hatz et al. 1991). In both cases, all LA-ICP-MS results were taken into consideration for the artefacts. Furthermore, linear discriminant analysis was applied to search for differences between groups for the following values: $\mathrm{Pb}^{206} / \mathrm{Pb}^{207}, \mathrm{~Pb}^{207} / \mathrm{Pb}^{204}$ and $\mathrm{Pb}^{208}$ / $\mathrm{Pb}^{206}$, as well as $\mathrm{Pb}^{206} / \mathrm{Pb}^{207}$ and $\mathrm{Pb}^{208} / \mathrm{Pb}^{206}$ in the case of the provenance analysis.

Moreover, a KDE model (Baxter 2003, 2016) proved useful, as it allows to create a continuous function describing the probability distribution of the lead isotopic ratios being an effect of the heterogeneity of metal in the examined artefacts. An example of such a model is presented in Fig. 16.

Having analysed lead isotopic ratios presented as scatterplots and using the kernel density estimation of these ratios, one can draw conclusions about the provenance of silver in the sample. If the values of lead isotopic ratios change in one direction continuously from point to point, which is visible as a significant peak width, or the kernel function has several local maximums (see Fig. 16), one can suspect that the silver was re-melted (Merkel 2016; Eniosova 2009; Eniosova and Mitoyan 2011). Such a situation has been observed in all the studied artefacts.

Figure 17 and Table 4 (see also the Electronic supplement, 2. Linear Discriminant Analysis - Ornaments) offer an LDA lead isotope ratio distribution in four technological groups. The analysis demonstrates that the raw material is similar with regard to its isotopic ratios in almost all the examined groups. Data obtained from the LDA confusion matrix demonstrates that the highest lead isotope homogeneity can be seen in the case of the West Slavic ornaments from Rajsków (WSR) ( $89 \%$ correct classifications). The percentage of correct classifications is much lower for post-Moravian ornaments (merely $35 \%$ ), while no correct classification was obtained for Scandinavian ornaments and West Slavic ones from Słuszków.

The LDA (Fig. 18, see also the Electronic supplement, 5. Linear Discriminant Analysis_-Provenance, Confusion matrix for the training sample) of the geological data
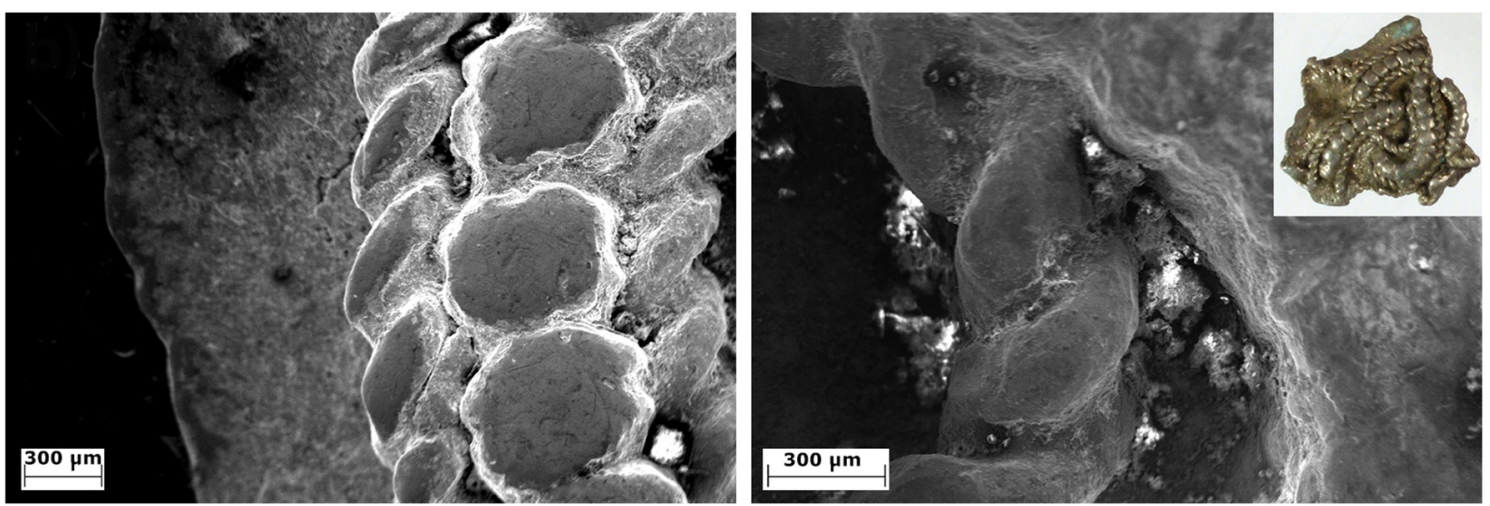

Fig. 11 Round pendant (Fig. 3c, no. 2) from the Rajsków hoard, Scandinavian type — general view and SEM-SE images of the soldering region 

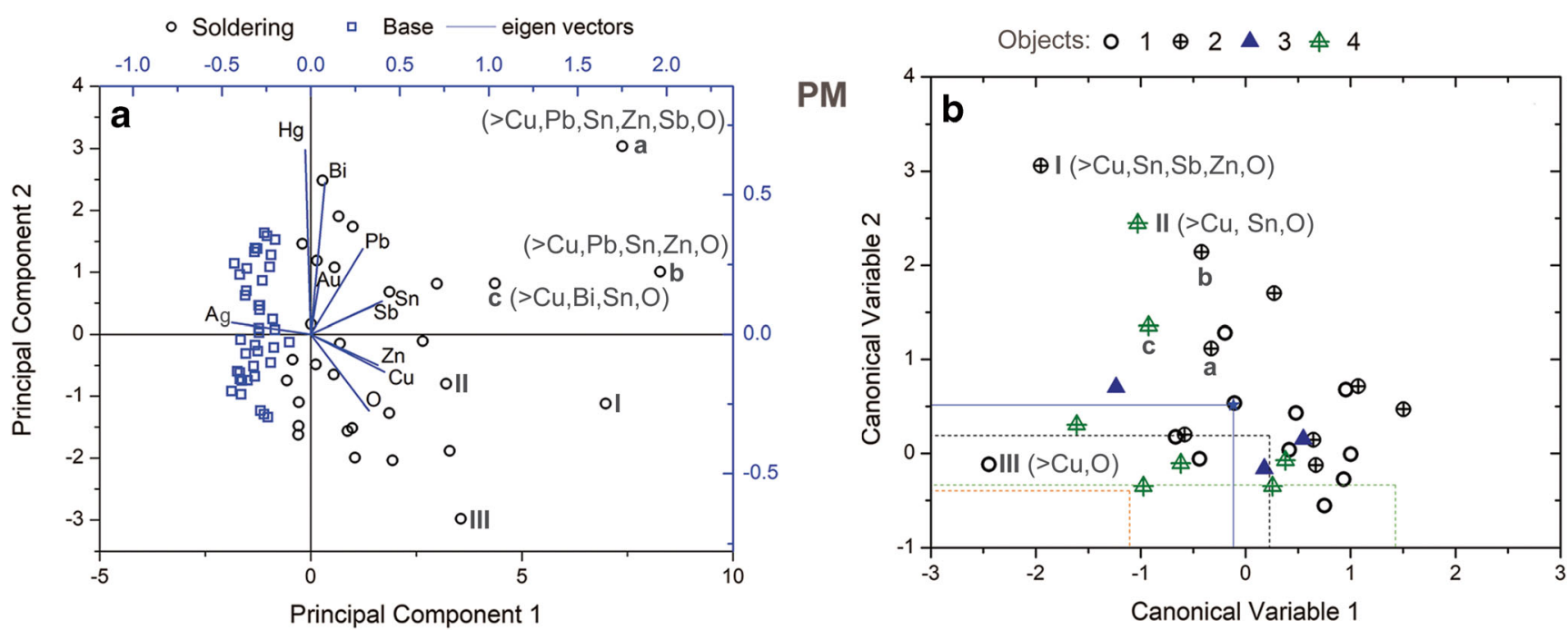

Fig. 12 Post-Moravian-type finds with granulations from the Rajsków hoard presented in Fig. 3a as nos. 1-4 (PM type): a PCA results for the base surface and the soldering area and $\mathbf{b}$ LDA results for the soldering area of individual artefacts from this group (zoom of Fig. 9b)

demonstrates a strong similarity between ores. Out of 17 deposits, a reasonable percentage of correct classifications was obtained in four cases only. The following deposits are clearly different from others: Afghanistan, Freiberg (Germany) and the Tatro-veporit unit (Slovakia)-100\% of correct classifications. There is also a good isolation for Uzbekistan (76\% of correct classifications). The assemblages of Rammelsberg (Germany), Gammersham (Germany) and Neo-volcanic deposits are classified into the Tatro-veporit unit in $100 \%$ of cases. The isotopic composition of samples from the Polish deposits of Olkusz-Chrzanów-Pomorzany (marked as OlkChPom) and the Slovak deposit of Gemer is also similar to the Slovak Tatro-veporit deposits.

This rather poor separation of deposits on the basis of $\mathrm{Pb}$ isotopic ratios strongly influences the results of provenancing attempts. Results of 701 analyses on the discussed artefacts were processed by LDA, but in most cases (see Electronic supplement, 5. Linear Discriminant Analysis-Provenance, Results for the prediction sample), no clear attribution to any deposit was achieved. It was conservatively assumed that a classification could be considered reliable when the prediction of probability was at least $70 \%$. Thus, only in 250 cases (that is, $36 \%$ ), a more or less unambiguous classification was obtained. Not surprisingly, the metal in the artefacts was mostly attributed to those deposits which were clearly different than others.

Furthermore, these results demonstrate that the metal in a given artefact may be of different origin (see Electronic supplement, 5. Linear Discriminant Analysis-Provenance, Results for the prediction sample). This supports the assumption of re-cycling and re-melting of raw material from various sources.

As it can be seen in Table 5 (see also the Electronic supplement, 5. Linear Discriminant Analysis-Provenance, Results for the prediction sample, and 6. Summaric results for provenance), the isotopic composition in individual groups results from the fact of mixing of the raw material from Central Asian (Afghanistan and Uzbekistan), German (Freiberg) and Polish ores. Interesting conclusions can be drawn from the analysis of individual groups. In all Slavic groups (that is, both West Slavic and post-Moravian), there is a preponderance of Freiberg silver over that from Uzbekistan and Afghanistan (if considered separately). However, it seems that in total the Asian raw material still played the most important role (Merkel 2016; Eniosova 2009). There are also some differences between groups of
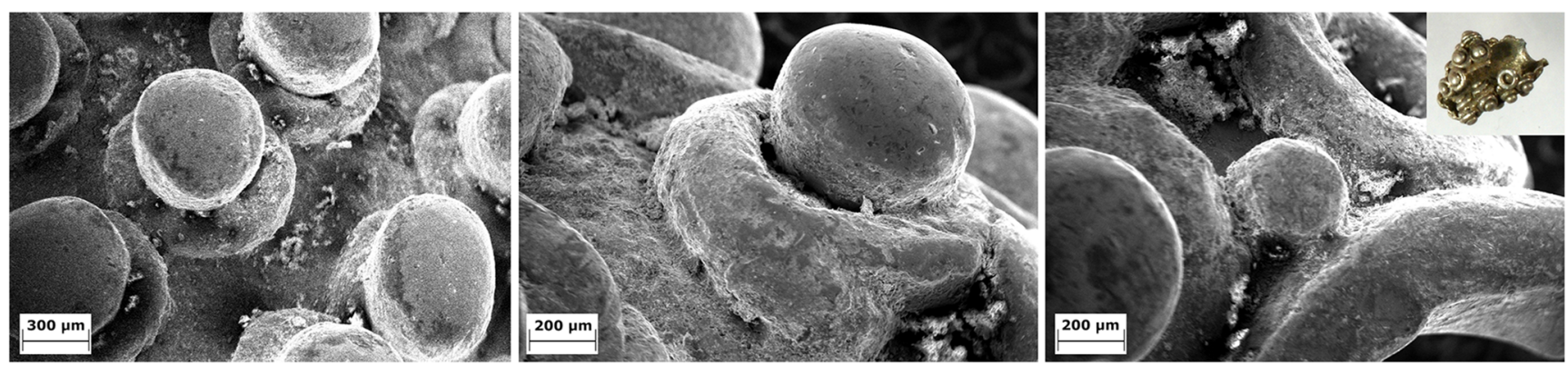

Fig. 13 Raspberry pendant (Fig. 3a, no. 2) from the Rajsków hoard, post-Moravian type-general view and SEM-SE images of the soldering region 

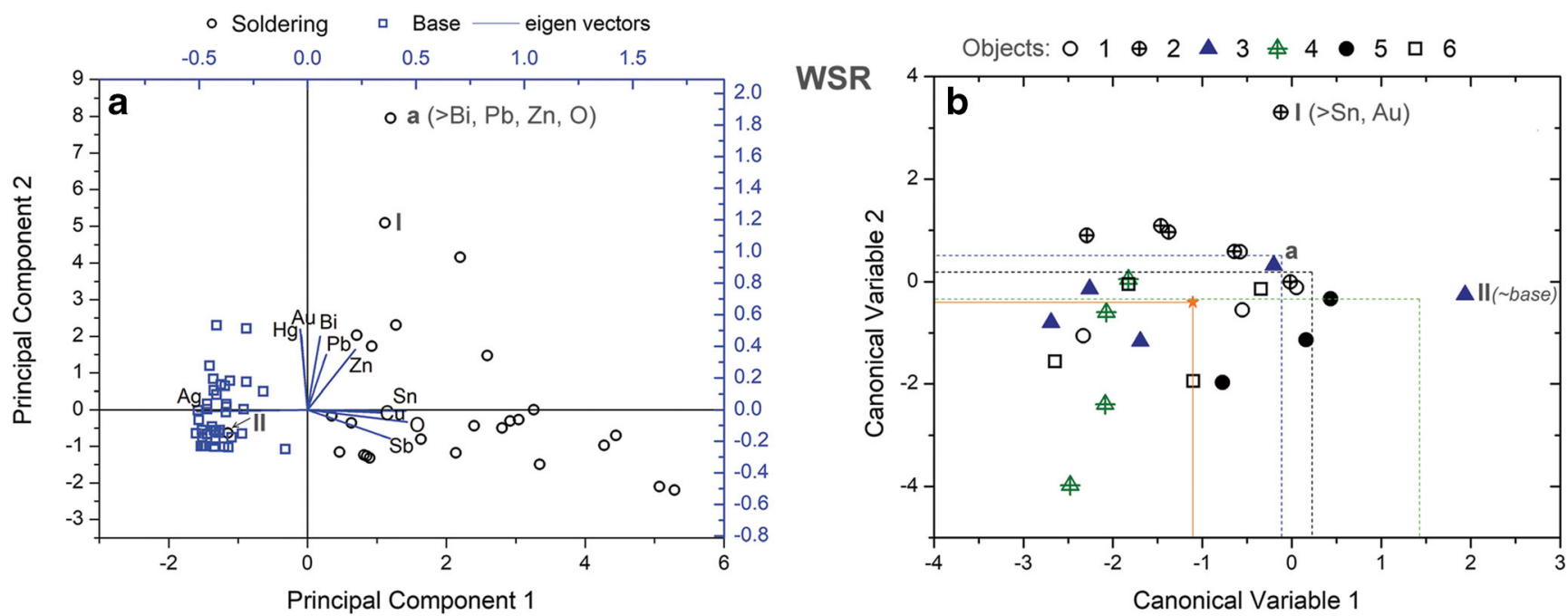

Fig. 14 West Slavic-type finds with granulations from the Rajsków hoard presented in Fig. 3b as nos. 1-6 (WSR type): a PCA results for the base surface and the soldering area and $\mathbf{b}$ LDA results for the soldering area of individual finds from the group (zoom of Fig. 9b)

Slavic jewellery concerning the share of individual deposits. What is most striking, however, is a very different proportion of metal from various sources in Scandinavian jewellery. The share of European deposits is $32 \%$, while nearly $70 \%$ of metal seems to have come from Asian sources. Of course, these observations must be treated with care. First of all, the number of the examined artefacts was not very high, which may pose problems for the statistical representativeness of results. Furthermore, the aforementioned rather poor separation between individual deposits must be taken into consideration. Last, but not least, a problem of missing sources must be borne in mind. That is, the LDA-based statistical processing of data will classify given observations only to those deposits which are present in the assemblage. Silver which was used in the discussed artefacts could also come from other deposits, whose isotopic composition may be similar to those which were included into the analysis.

\section{Discussion}

\section{Jewelleries craft}

A significant part of the investigated jewellery from the Rajsków and Słuszków hoards is granulated. The results show that these elements are permanently bonded to the substrate by the process based on the use of copper compounds (Kolářová et al. 2014). The properties of solder based on $\mathrm{Ag}-\mathrm{Cu}$ are widely described in Nature (Ashkenazi et al. 2017). Intentional doping of silver with copper up to $2.6 \mathrm{wt} \%$
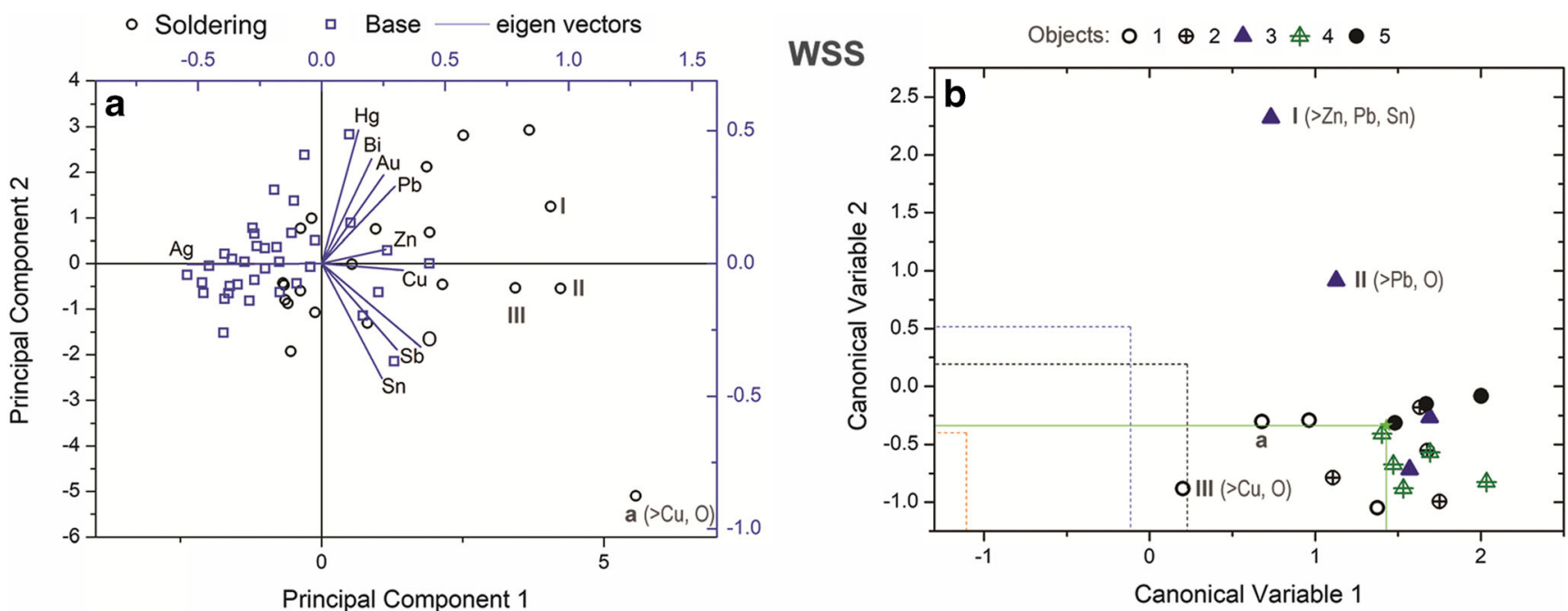

Fig. 15 West Slavic-type finds with granulations from the Słuszków hoard presented in Fig. 2 as nos. 1-5 (WSS type): a PCA results for the base surface and the soldering area and $\mathbf{b}$ LDA results for the soldering area of individual artefacts from the group (zoom of Fig. 9b) 

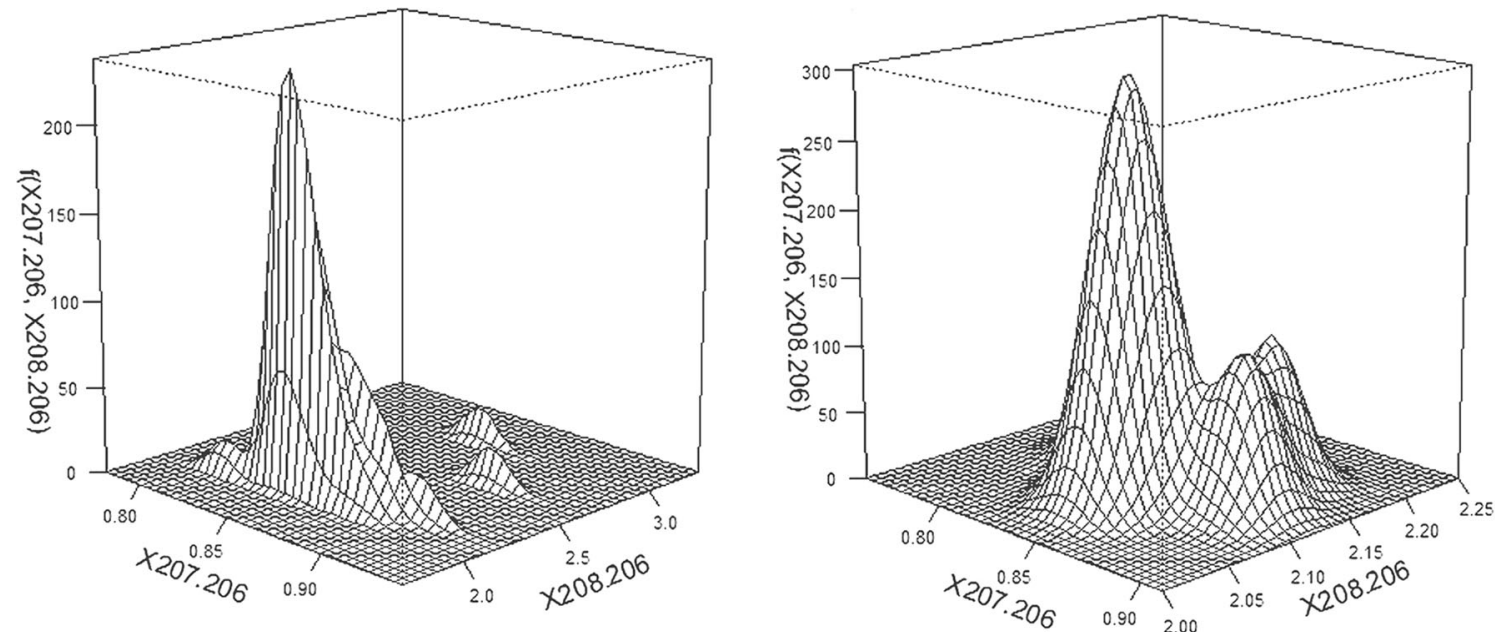

Fig. $16 \mathrm{KDE}$ calculated (surface plot of a scatterplot) for lead isotope ratios $\mathrm{Pb}^{207 / 206}$ and $\mathrm{Pb}^{208 / 206}$ for two artefacts from the Rajsków hoard as an example of re-melted samples

(Ashkenazi et al. 2017) causes the melting point of $\mathrm{Ag}-\mathrm{Cu}$ alloy to be lower than $961{ }^{\circ} \mathrm{C}$ for pure $\mathrm{Ag}$ (Tuah-Poku et al. 1988; Bastow 2013). From an old handbook (twelfth century receipts of Theophilus Presbyter; Pliny 1929; Leyden Papyrus $\mathrm{X})$, two types of soldering-metallic and non-metallic (chemical) - are known. These were discussed in detail by Duczko (1985, p. 26-28).

Metallic solders known from the third century BC are mixtures of two or three metals (Wolters 1978, p. 5; 1983, p. 62). While silver artefacts are soldered, the main component is Ag, while other additions could be gold, brass or tin (Wolters 1978,1983 , p. 61ff). The obtained soldering effect is not artistically convincing. The solder mixture covers the entire surface between the ornaments and the base surface (Carrol 1974, p. 35; Kolářová et al. 2014). The use of metallic soldering is particularly advantageous when joining larger and more durable jewellery items. However, using metal solder for

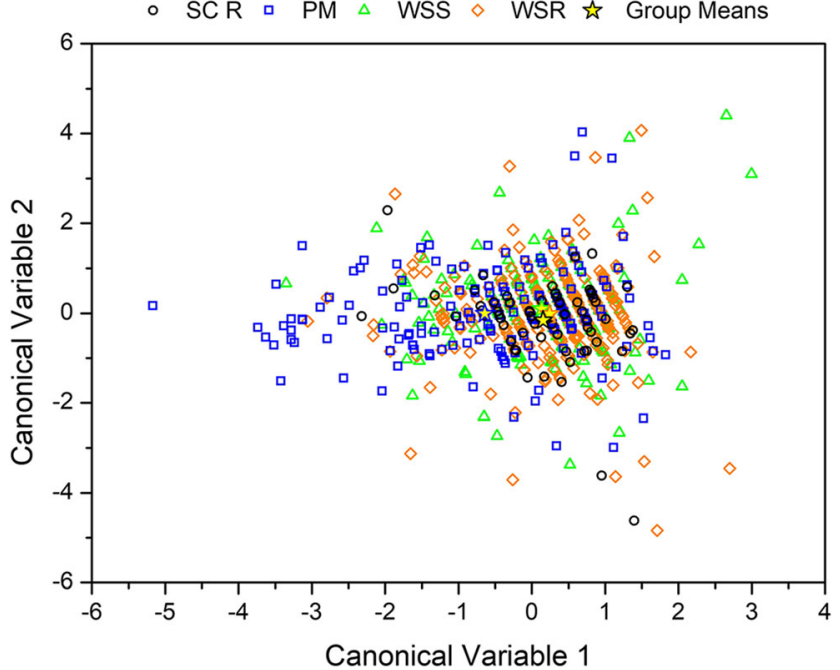

Fig. 17 LDA showing $\mathrm{Pb}^{206} / \mathrm{Pb}^{207}, \mathrm{~Pb}^{207} / \mathrm{Pb}^{204}$ and $\mathrm{Pb}^{208} / \mathrm{Pb}^{206}$ variability in four groups of ornaments decoration is more problematic for filigree jewellery and granulation. When melted, the solder is not absorbed into the surface and forms a "puddle" in which small decorative elements melt (Eilbracht 1999). This type of soldering has been identified by Macháček et al. (2016) during their study of the Great Moravian jewellery and on the ornaments from the "Lumbe Garden" cemetery at Prague Castle (Ottenwelter et al. 2014, p. 283). In line with what was said above, the spilled granulation (see Figs. 5 and 6) with higher contents of $\mathrm{Pb}$ and $\mathrm{Cu}$ (added as a joining Ag-based mixture) in the soldering area (Table 1) is characteristic for the beads from Słuszków hoard. The beads are remarkable for their relatively ungrouped granules, so the assumption concerning the application of metallic soldering is justified. The granules are tiny $(300-400 \mu \mathrm{m})$ and the solder is spilled over all the surface (see LDA: Table 3, Fig. 10a). Apart from that, the shape between granules which are close to each other is fuzzy (see Fig. 5). The WSS group soldering area is strongly different from that in the remaining jewellery under study (Fig. 9b, Table 3).

The remaining part of the examined jewellery with granulation and filigree from Rajsków (post-Moravian and West Slavic types) and Stojkowo (Scandinavian type) demonstrates traces of use of the non-metallic (chemical, bonding) soldering. Non-metallic solders consist either of mineral or artificially produced copper compounds (Duczko 1985). Written sources described a few such substances: malachite (in antiquity called chrysocolla) and azurite, naturally occurring forms of basic copper carbonate; patina (i.e. a copper alloy resembling enamel covering old bronze artefacts - mostly copper carbonate, containing natural oxides and oxides of bronze additives - tin, lead, zinc, arsenic); verdigris, a mixture of basic copper acetate and copper acetate pentahydrate, produced by the action of vinegar on copper; and Roman vitriol, cupric sulphate pentahydrate (Tamla 2016). In order to prepare a diffusion agent, a copper compound is added to a mixture of 
Table 4 LDA confusion matrix for the training sample. Data obtained for lead isotope ratios: $\mathrm{Pb}^{206} / \mathrm{Pb}^{207}, \mathrm{~Pb}^{207} / \mathrm{Pb}^{204}$ and $\mathrm{Pb}^{208} / \mathrm{Pb}^{206}$ in the jewelleries' groups
Fig. 18 LDA showing $\mathrm{Pb}^{206}$ / $\mathrm{Pb}^{207}$ and $\mathrm{Pb}^{208} / \mathrm{Pb}^{206}$ variability for geological data (means) obtained from the literature

\begin{tabular}{lclllrr}
\hline $\begin{array}{l}\text { From/to } \\
n(\%)\end{array}$ & PM & Sc.R & WSR & WSS & Total & \% correct \\
\hline PM & $58(35 \%)$ & $0(0 \%)$ & $107(65 \%)$ & $0(0 \%)$ & $165(100 \%)$ & 35 \\
Sc.R & $5(7 \%)$ & $0(0 \%)$ & $65(93 \%)$ & $0(0 \%)$ & $70(100 \%)$ & 0 \\
WSR & $32(11 \%)$ & $0(0 \%)$ & $266(89 \%)$ & $0(0 \%)$ & $298(100 \%)$ & 89 \\
WSS & $25(15 \%)$ & $0(0 \%)$ & $142(85 \%)$ & $0(0 \%)$ & $167(100 \%)$ & 0 \\
\hline
\end{tabular}

$n$ number of measurements

- OlkuszChPom o Rammelsberg $\Delta$ Gammersheim $\diamond$ Freiberg t* Tatro-veporit unit $\diamond$ Neo-volcanic $\triangleright$ Gemer $\nabla$ Afghanistan

- Uzbekistan $\oplus$ Buchberg $\oplus$ Harz $\boxplus$ Oberlausitz

* Pribram $\otimes$ Horbach $\otimes$ KutnaHora NaSlupi
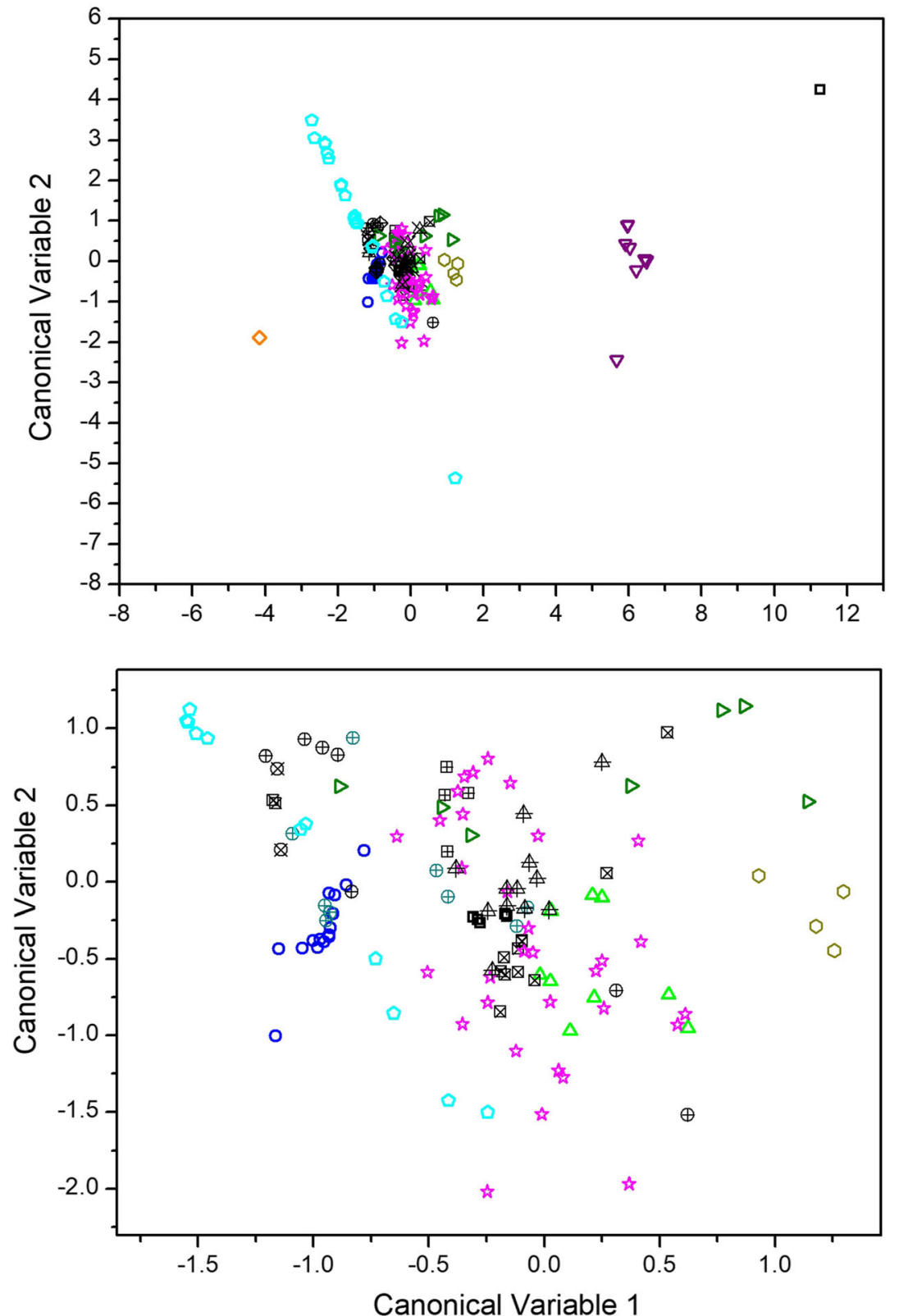
Table 5 Results of LDA ore provenance classification for four jewelleries' groups

\begin{tabular}{ccccccc}
\hline & $\begin{array}{l}\text { Number of } \\
\text { analyses }\end{array}$ & $\begin{array}{l}\text { Prediction } \\
\text { Freiberg }\end{array}$ & $\begin{array}{l}\text { Prediction } \\
\text { Uzbekistan }\end{array}$ & $\begin{array}{l}\text { Prediction } \\
\text { Afghanistan }\end{array}$ & $\begin{array}{l}\text { Prediction } \\
\text { OlkuszChPom }\end{array}$ & $\begin{array}{l}\text { Prediction } \\
\text { Gammersham }\end{array}$ \\
\hline WSS & 68 & $25(37 \%)$ & $18(26 \%)$ & $18(26 \%)$ & $6(9 \%)$ & $1(1 \%)$ \\
WSR & 90 & $27(30 \%)$ & $31(34 \%)$ & $22(24 \%)$ & $10(11 \%)$ & $0(0 \%)$ \\
PM & 73 & $28(38 \%)$ & $22(30 \%)$ & $14(19 \%)$ & $9(12 \%)$ & $0(0 \%)$ \\
Sc.R. & 19 & $5(26 \%)$ & $10(53 \%)$ & $3(16 \%)$ & $1(5 \%)$ & $0(0 \%)$ \\
Total & 250 & $85(34 \%)$ & $81(32 \%)$ & $57(23 \%)$ & $26(10 \%)$ & $1(0 \%)$ \\
\hline
\end{tabular}

an organic adhesive (e.g. gum tragacanth, gum acacia, fishglue) and water. Sometimes, such mixture is enriched by socalled asem described by Leyden Papirus X (Demortier et al. 1999). The nature of asem is unknown, but this term is used in an old handbook with reference to a substance whose properties are similar to precious metals (Berthelot 1889). With this solution, the decorative elements are fastened to the substrate, and the artefact is then heated (Wolters 1983).

In reference to what was said above, the granulation and wire-ornamented West Slavic (WSR), post-Moravian type (PM) and Scandinavian finds from the Rajsków hoard show $\mathrm{Cu}, \mathrm{Sn}$ and $\mathrm{Sb}$ (see Table 1) enrichments with a higher oxidation degree in the soldering area (see Figs. 7, 8, 11 and 13). The content of $\mathrm{Cu}$ (which is a melting agent) is up to $57.3 \mathrm{wt} \%$. This gives a melting temperature over $779{ }^{\circ} \mathrm{C}(\mathrm{a}$ lower value occurs for $28.1 \mathrm{wt} \% \mathrm{Cu}$ ) (Ashkenazi et al. 2017). The soldering regions of all three archaeological types from the Rajsków hoard are similar (see Fig. 9b, Table 3). These are characterised by a good separation from the base surface (see Tables 1 and 2). Furthermore, the bonding area with a higher content of copper $(\mathrm{Cu})$ is enriched in low-melting elements (Sn, Sb, Zn; Baxter 2003). These were presumably intentionally added to the alloy as asem in diffusion bonding or as part of a $\mathrm{Cu}$-based mixture. The oxidation of the soldering region is correlated with the presence of $\mathrm{Cu}$ and $\mathrm{Zn}$ in postMoravian-type artefacts (see Fig. 12a), with the presence of $\mathrm{Sb}, \mathrm{Cu}$ and $\mathrm{Sn}$ in West Slavic finds (see Fig. 14a) and with the enrichment in $\mathrm{Sb}$ and $\mathrm{Sn}$ in Scandinavian finds (see Fig. 15a). Generally, the presence of the oxide structure in the joining region, around the granules and wires, could result from enough reducing atmosphere during the chemical soldering or could be an effect of improper heat treatment. If soldering is to be successful, it is essential for the metal surfaces to be absolutely clean. This is because a series of thermal treatment reactions occurs during this process: at $100^{\circ} \mathrm{C}, \mathrm{CuO}$ is formed from $\mathrm{Cu}$ compounds; at $600{ }^{\circ} \mathrm{C}$, the reducing atmosphere is created by glue carbonising; and at $850{ }^{\circ} \mathrm{C}, \mathrm{Cu}$ oxides are reduced to $\mathrm{Cu}$ by $\mathrm{CO}$ (Duczko 1985, p. 25). Heating above $900{ }^{\circ} \mathrm{C}$ causes the metallic copper to diffuse to the base surface and to the alloy of ornaments (Wolters 1983, p. 57). Charcoal fuel was used as a temperature agent. It has certain properties which render it particularly suitable for soldering operations. It generates high temperatures necessary for the processing of gold, silver and copper. Burning charcoal maintains a temperature of $800{ }^{\circ} \mathrm{C}$ without an artificial air supply. The temperature increases to $1300{ }^{\circ} \mathrm{C}$ when air is supplied through a single pair of bellows or a blow-pipe (tools primarily required for minor soldering operations). If there is a continuous blast from water-powered double bellows, the temperature rises as high as $1650{ }^{\circ} \mathrm{C}$ (Untracht 1985). The other property of charcoal is the ability to create a reducing atmosphere, which protects the heated metal from oxygen in the air. This is important due to the presence of copper and other easily oxidising elements (such as zinc, tin, antimony in our cases) in solder alloys. When heated, those elements produce oxides, which coat the surface of the artefacts, thus preventing the completion of the soldering process, which is visible in Figs. 7, 8, 11 and 13. If charcoal fire is not sufficient to completely eliminate oxidisation, it is necessary to use a special anti-oxidisation agent, called flux which coated all the joints. The following substances could be used as flux: soda (sodium bicarbonate $\mathrm{NaHCO}_{3}$ ), tartar (potassium bitartrate $\mathrm{KC}_{4} \mathrm{H}_{5} \mathrm{O}_{6}$ ), alum (hydrated potassium aluminium sulphate $\mathrm{Kal}\left(\mathrm{SO}_{4}\right)_{2} \cdot 12 \mathrm{H}_{2} \mathrm{O}$ ), potash (potassium carbonate $\mathrm{K}_{2} \mathrm{CO}_{3}$ ) and the most important factor, that is, borax (sodium tetraborate $\mathrm{Na}_{2} \mathrm{~B}_{4} \mathrm{O}_{7}$ ). All these substances are well documented in historical sources (Wolters 1978).

Furthermore, the presence of $\mathrm{Zn}$ and $\mathrm{Sb}$ in the joining mixture can be associated with the use of such minerals as tetrahedrite ( $[\mathrm{Cu}, \mathrm{Fe}]_{12} \mathrm{Sb}_{4} \mathrm{~S}_{13}$ ) (Munoz et al. 2015), which is also a source of copper, and sphalerite $(\mathrm{ZnS})$. The latter is often found with Ag-rich galena deposits $(\mathrm{PbS})$ which were the main source of silver in medieval Poland and Europe (Gale and Stos-Gale 2000; Chamberlain and Gale 1980). Furthermore, antimony is associated with freibergite mineral $\left[\mathrm{Ag}_{6}\left(\mathrm{Cu}_{4} \mathrm{Fe}_{2}\right) \mathrm{Sb}_{4} \mathrm{~S}_{13-x}\right]$ which characterised Freiberg (Germany) silver ores based on galena and sphalerite boards. Antimony-rich deposits were also located in Poland in Lower Silesia, e.g. in Dębowiny in the Beskidy Mountains between Srebrna Góra and Złoty Potok (Mączka and Stysz 2008). In the Early Middle Ages, silver was extracted in this region by a refining process called cupellation. The aforementioned minerals which may have been a source of elements used to produce soldering mixture could be added as asem part to resin glue being a binder in non-metallic soldering. Moreover, with regard to the antimony content, we may assume that our 
ornaments were made of silver from cupellation directly associated with this element. An important thing in the cupellation process is wasting of silver by evaporation and dissolution of silver in lead oxide $(\mathrm{PbO})$ and later soaking into a cupel (alkaline-for example from animal bone bound with potash). An optimal amount of lead must be selected - and this already shows the quality of the workshop (the same as the temperature of the furnace, the amount of copper admixture and the quality of the cupel itself). Also, a significant influence on silver wasting is exercised by the addition of antimony and tellurium which facilitate silver infiltration into the cupel. If the addition of these elements actually took place in order to produce raw silver of the studied jewelleries, antimony would be present in the entire artefact and not only in the solder region.

From "De Re Metallica" of Agricola (the work is of a sixteenth century date, but it also discusses much earlier technologies), we learn that the stibium mineral (probably antimonite or other antimony minerals) was used, among others, for the metallurgical process of recovering gold from pyrite. Excepting reduction with silver, and separation with nitric acid and a method of reduction with lead and silver, followed by cupellation and parting with nitric acid is the third method that can be isolated. Yet another method is the reduction with lead or antimony, followed by cupellation. The use of sulphur or antimony sulphide would tend to part out a certain amount of silver and thus to obtain fairly pure bullion upon cupellation.

Silver was also parted from gold by means of stibium. The use of antimony sulphide to part silver from gold is based upon a greater affinity of silver than antimony to sulphur. Thus, the silver, as in other processes, is converted into a sulphide and is absorbed in the regulus, while the metallic antimony alloys with the gold and settles on the bottom of the pot. This process has several advantages over the sulphurisation with crude sulphur; antimony is a more convenient vehicle of sulphur, for it saves the preliminary sulphurisation with its attendant difficulties of volatilisation of the sulphur; it also saves the granulation necessary in the former method; eventually, the treatment of the subsequent products is simpler.

The process in this description can be divided into six operations: (a) sulphurisation of the silver by melting it with antimony sulphide; (b) separation of the gold "lump" (massula) by jogging; (c) re-melting the regulus (mistura) three or four times for a recovery of further "lumps"; (d) remelting of the "lump" four times, with further additions of antimony sulphide; (e) cupellation of the regulus in order to recover the silver; and (f) cupellation of the antimony from the "lump" to recover the gold (Agricola 1912, p. 451).

The method described by Agricola for treating antimony sulphide was still in use in the twentieth century in the Harz, in Bohemia and elsewhere. The stibnite was liquated out at a low heat and then it dripped from the upper to the lower pot. The resulting purified antimony sulphide is the modern commercial "crude antimony" or "grey antimony" (Agricola 1912, p. 428).

In the case of mercury content in all studied artefacts, this element was widely used in workshops working with precious metals, especially gold. Vitruvius in his work "On architecture ..." (Agricola 1912, p. 123) said: "Mercury is suitable for many purposes. Without it, you can not gild either silver or bronze [...] mercury attracts all gold particles and connects with it." Theophilus (1979) in his recipes recommends it, among others, as an additive for grinding gold or silver (five parts of mercury and six parts of silver), for obtaining the socalled sand (extracted from the sand mined on the banks of the Rhine) or as an alloy for casting tin vessels (one quarter pound of tin for one pound of tin) and final polishing of these castings (a mixture of dissolved tin chips in mercury). Therefore, the presence of gold and mercury in the results of research on the ornaments is probably not intentional (traces after amalgam gilding) but results from contamination, for example, with components of a solder or alloy intended for granulation.

\section{Assessing provenance}

When analysing the origin of the raw material, it should be remembered that metal artefacts are not geological ores. The objects are created by a series of anthropogenic actions, such as extraction of raw metal, re-cycling or alloying with other metal. These actions cause the artefact's structure to be heterogeneous in the micro-scale. This is reflected in the heterogeneity of the chemical composition-elemental and isotopic character of the artefact (Liu et al. 2018). Therefore, the measured composition is merely a resultant of an average of the composition. For this reason, the interpretation of the obtained results may be burdened with an error, and it should be treated as a subject for further verification. Furthermore, it could be suggested that apart from $\mathrm{Pb}$, other isotopic ratios may also be of use, for example $\mathrm{Cu}$ and $\mathrm{Ag}$ (Desaulty et al. 2011). Quite promising results have recently been obtained in iron provenance studies which employed Os isotopic signatures (Dillmann et al. 2017, with further reading).

Three phases of silver inflow are isolated for Poland in the Early Middle Ages (tenth to twelfth century). In the first phase which falls within the pre-state period (to the end of the tenth century), there is a preponderance of oriental silver, chiefly Arab dirhams (Burâkov 1965, 1974; Bubnova 1963; Cowell and Lowick 1988; Dekówna 1971, p. 496, 487; Merkel 2016; Eniosova 2009; Eniosova and Mitoyan 2011). For about 250 years (since the eighth to the mid-tenth century), dirhams are the main component of hoards found in Poland. This changes in the second half of the tenth century, when Western European coins and then local issues commence to prevail. This second wave of inflow (second half of the tenth 
to late eleventh century) was related to a dominant role of coins which were coming to Poland from Western European countries, chiefly from Germany, where enormous deposits of silver were discovered in the Harz in the Rammelsberg mine in the third quarter of the tenth century (Jammer 1952, p. 62; Suchodolski 1971, p. 22). The third phase is related to the use of native silver and is well visible in finds since the rule of Bolesław Krzywousty (1107-1138).

Due to the technological nature of the artefacts, i.e. their heat treatment and a considerable blur of intentionally added layers, there seems to be little point in attempting at interpreting the elemental composition in relation to the composition of individual geological deposits. More so, because the discussed silver deposits are $\mathrm{PbS}$ and $\mathrm{ZnS}$ systems with similar additives. What is remarkable is the aforementioned presence of $\mathrm{Sb}$ in the deposits from Freiberg and from Lower Silesia. The percentage share of individual elements in the artefacts does not reflect the initial composition of the deposit, which was first extracted from the ore. Then, the obtained raw material was melted and intentional additives were added in order to receive the desired technological parameters.

The results of the $\mathrm{Pb}$ isotope ratio study provide grounds for concluding that the silver used to produce the discussed early medieval artefacts comes from different sources and ores (Table 5). This means that the investigated ornaments may have been made of silver coming from various other artefacts and ores. The results of our investigations may suggest the silver used for manufacturing the discussed jewellery chiefly originated from Asia (Uzbekistan and Afghanistan) or Freiberg in Germany.

\section{Conclusions}

The obtained results provide detailed information about the technological aspects of early medieval silver ornaments from Central and Eastern Europe and allow for an isolation of two types of soldering. In the future, on the basis of studies on larger assemblages, it may be possible to propose a new and more relevant archaeological classification of these finds. This classification can be regarded as valid after a thorough examination and comparison of all the studies of ornaments from other West Slavic and Scandinavian territories. Research on jewellery allows to introduce the Slavic tradition to the art history and material culture of Europe. Until now, this tradition has been largely unknown to the world science due to the lack of relevant studies. So far, Polish scholars have made only one attempt at solving the problem of similarity of technological decorations in the Slavic territories. Unfortunately, this study was based on insufficient source materials (ZollAdamikowa et al. 1999). The latest work of Czech researchers is very promising (Čáp et al. 2011; Galuška 2013; Ottenwelter et al. 2014; Macháček et al. 2016; Kolářová et al. 2014).
However, at present, it is difficult to compare all previously published studies (Gójska et al. 2019)—most of the performed analyses were obtained by X-ray fluorescence spectrometry (XRF) or X-ray microanalysis spectrometry (EDX) on surfaces (often corroded or contaminated), which may produce distorted results. This method is not accurate when examining the raw material of the base surface, and the solder area is usually analysed along with the entire metal surface, which can distort the quantitative reading of elements (Ottenwelter et al. 2014). Nevertheless, studying ornaments by surface techniques we obtain preliminary information about their structure and chemical composition. In order to compare the raw material of alloys and silversmiths used in early medieval Europe, it is necessary to continue systematic archaeometric research on similar ornaments, also with the use of invasive preparation (Kolářová et al. 2014) in order to establish a database of comparative data.

Studies on aesthetically and technologically advanced artefacts from the Early Middle Ages reveal a completely new aspect of the Slavic culture and are the basis for undertaking international cooperation in methodological research on similar finds from the Czech Republic and Scandinavia. Submitted results confirm a crucial role played by different complementary analytical techniques, in particular SEMEDX, LA-ICP-MS and also lead isotope ratios and statistical methods in order to identify combined techniques used in silver ornaments and to establish the origin of the raw material.

Funding information This work was has been carried out with the financial support of the National Research Centre in Cracow, Poland (grant no. UMO-2013/09/B/HS3/03289).

Open Access This article is distributed under the terms of the Creative Commons Attribution 4.0 International License (http:// creativecommons.org/licenses/by/4.0/), which permits unrestricted use, distribution, and reproduction in any medium, provided you give appropriate credit to the original author(s) and the source, provide a link to the Creative Commons license, and indicate if changes were made.

\section{References}

Agricola G (1912) De Re Metallica. Translated from the first latin edition of 1556 by Hoover HC and Hoover LH.: London

Ashkenazi D, Gitler H, Stern A, Tal O (2017) Metallurgical investigation on fourth century BCE silver jewellery of two hoards from Samaria. Sci Rep:1-14. https://doi.org/10.1038/srep40659

Ashkenazi D, Gitler H, Stern A, Tal O (2018) Archaeometallurgical characterization and manufacturing technologies of fourth century BCE silver jewelry: the Samaria and Nablus hoards as test case. Metallography, Microstructure, and Analysis 7(4):387-413

Baines R (2005) The reconstruction of historical jewellery and its relevance as contemporary artefact, $\mathrm{PhD}$ thesis at Royal Melbourne Institute of Technology, Melbourne, https://researchbank.rmit.edu. au/eserv/rmit:6273/Baines.pdf. Accessed 17.08.17 
Baker J, Stos S, Waight T (2006) Lead isotope analysis of archaeological metals by multiple-collector inductively coupled plasma mass spectrometry. Archaeometry 48(1):45-56

Bastow E (2013) Solder families and how they work, low meltingtemperature alloys are vital to successful electronics assembly, Indium Corp. of America, Utica, New York, http://ostec-materials. ru/upload/iblock/714/71418246221db5e84a71e8973b38f94e.pdf. Accessed 7.08.04

Baxter JM (2003) Statistics in archaeology, Arnold

Baxter M (2016) Multivariate analysis of archaeometric data. An introduction https://www.academia.edu/24456912/Multivariate Analysis_of_Archaeometric_Data_An_Introduction. Accessed $1 \overline{7}$ Aug 04

Berthelot M (1889) Introduction á d'éla chimie des anciens et du MoyenAge Editions. Georges Steinheil, Paris

Bubnova MA (1963) Dobyča serebro-svincovych rud v Šel'dži v IX-XII vv., [In]: Arheologičeskie pamâtniki Tallaskoj doliny, Frunze, pp 225-262

Budd P, Haggerty A, Pollard MA, Scaife B, Thomas GR (1995) New heavy isotope studies in archaeology. Israel J Chem 35:125-130

Burâkov ǓF (1965) Drevnij serebrânnyj rudnik Laškerek, Sovetskaâ Arheologiâ, no 1: 282-289

Burâkov ǓF (1974) Gornoe delo I metallurgiâ srednevekogo Ilaka V nacala XIII v., Moskva

Čáp P, Macháček J, Špaček J, Hložek M (2011) Tajemství výroby velkomoravského šperku. Archeologický experiment. Koniasch Latin Press, Praha

Carrol DL (1974) A classification for granulation in ancient metalwork. AJA 78:33-39

Cattin C, Guénette-Beck B, Besse M, Serneels V (2009) Lead isotopes and archaeometallurgy. Archaeol Anthropol Sci 1:137-148

Chamberlain V, Gale HN (1980) The isotopic composition of lead in Greek coins and in galena from Greece and Turkey. [in:]: A.E. Slater, O.J. Tate (Eds.) Proceedings of the 16th international symposium on archaeometry and archaeological prospection, Edinburgh 1976. The National Museum of Antiquities of Scotland, pp. In: 139 155

Costa V (2001) The deterioration of silver alloys and some aspects of their conservation. Stud Conserv 46(1):18-34

Cowell MR, Lowick NM (1988) Silver from the Panjhĩr mines. In: Metallurgy in Numismatics, vol 2, London

Dekówna M (1971) Stan badań nad górnictwem srebra i tzw. kryzysem srebra w Azji Środkowej. Archeologia Polski t. XVI:483-501

Dekówna M (1974) Ozdoby i srebro lane. [In:] Dekówna M, Reyman J, Suchodolski S (eds.), Wczesnośredniowieczny skarb srebrny z Zalesia powiat Słupca, vol. In: 2: 240-51

Demortier G, Fernandez-Gomez F, Ontalba Salamanca MA, Coquay P (1999) PIXE in an external microbeam arrangement for the study of finely decorated tartesic gold jewellery items. Nuc Inst Methods Phys Res B 158:275-280

Desaulty AM, Telouk P, Albalat E, Albarède F (2011) Isotopic Ag- $\mathrm{Cu}-$ $\mathrm{Pb}$ record of silver circulation through 16th-18th century Spain. PNAS 108(22):9002-9007 https://doi.org/10.1073/pnas. 1018210108

Dillmann P, Schwab R, Bauvais S, Brauns M, Disser A, Leroy S, Gassmann G, Fluzin P (2017) Circulation of iron products in the North-Alpine area during the end of the First Iron Age (6th-5th c. $\mathrm{BC})$ : a combination of chemical and isotopic approaches. J Archaeol Sci 87:108-124. https://doi.org/10.1016/j.jas.2017.10.002

Duczko W (1972) Slavic silver jewellery from the Viking Period. An analysis of material from Gotland, C-uppsats i arkeologi. Uppsala Universitet, $\mathrm{p} 131$

Duczko W (1984) Die Kugelnadel aus Bj 832. In: Birka II/1: 1-4

Duczko W (1985) The filigree and granulation work of the Viking Period. An analysis of the material from Björkö (= Birka V), Stockholm
Duczko W (1986) Vikingatidens filigran- och granulationsarbeten. En analys av materialet från Björkö, In: Annales Societatis Litterarum Humaniorum Regiae Upsaliensis, Uppsala, pp 107-110

Duczko W (2015) Status and magic. Ornaments of elites buried at Bodzia [In:]: Bodzia. A late Viking-age elite cemetery in central Poland. Brill, Leiden-Boston, pp 202-221

Duczko W (2016) Moce wikingów. Światy i zaświaty wczesnośredniowiecznych Skandynawów, Warsaw

Duczko W (2018) Post-wielkomorawski fenomen. Wczesnośredniowieczna sztuka zlotnicza w Środkowej i Wschodniej Europie (Summary: post-Great Moravian phenomenon. Early Medieval goldsmithery in Middle and Eastern Europe). [In]: Inspiracje i funkcje sztuki pradziejowej i wczesnośredniowiecznej. Biskupin-Wrocław, pp 107-119

Eilbracht H (1999) Filigran und Granulationskunst im wikingischen Norden: Untersuchungen zum Transfer frühmittelalterlicher Gold und Silberschmiedetechniken zwischen dem Kontinent und Nordeuropa. In: Köln. Bonn, Rheinland-Verlag; Habelt

Eniosova NV (2009) Tracing the routes of silver procurement to the early urban centre Gnëzdovo in the 10th/early 11th centuries. In: Bendeguz T (ed) Die Archäolodie der Frühen Ungarn Chronologie, Technologie und Methodik, pp 261-283. Budapest

Eniosova N, Mitoyan R. (2011) Arabic coins as a silver source for Slavonic and Scandinavian jewellers in the tenth century AD. In: Turbanti-Memmi I (ed) Proceedings of the 37th international symposium on archaeometry, 597-584. Berlin

Ettler V, Johan Z, Zavřel J, Wallisová MS, Mihlajevič M, Šebek O (2015) Slag remains from the Na Slupi site (Prague, Czech Republic): evidence for early medieval non-ferrous metal smelting. J Archaeol Sci 53:72-83

Everitt BS, Hothorn T (2011) An introduction to applied multivariate analysis with R. Springer, Berlin

Everitt BS, Landau S, Leese M, Stahl D (2011) Cluster analysis. Wiley, Hoboken

Ferro D, Bedini A, Rapinesi IA (2009) Two small orientalising spirals (Rome, 10th-9th century BC) common objects - precious jewels. Archeo Sciences, revue d'archéométrie 33:165-168

Gale NH, Stos-Gale ZA (2000) Lead isotope analyses applied to provenance studies. [in:] E. Ciliberto, G. Spoto (Eds.) Modern analytical methods in art and archaeology. Wiley, New York, pp 503-584

Galuška L (2013) Hledání původu. Od avarských bronzů ke zlatu Velké Moravy. Moravské zemské muzeum, Brno

Gójska AM, Miśta EA (2016) Analysis of the elemental composition of the artefacts from the Kosewo archaeological site. Acta Phys Pol A 130(6):1415-1419. https://doi.org/10.12693/APhysPolA.130.1415

Gójska AM, Miśta-Jakubowska E, Banaś D, Kubala-Kukuś A, Stabrawa I (2019) Archaeological applications of spectroscopic measurements. Compatibility of analytical methods in comparative measurements of historical Polish coins. Measurement 135:869-874

Goldstein J, Newbury ED, Joy CD, Lyman EC, Echlin P, Lifshin E, Sawyer L, Michael RJ (2007) Scanning electron microscopy and $\mathrm{X}$-ray microanalysis, 3rd edn. Springer

Hatz G, Hatz V, Zwicker U, Gale N, Gale Z (1991) Otto-AdelheidPfennige. Commentationes de Nummis Saeculorum IX-XII In Suecia Repertis Nova Series 7 The Royal. Swedish Academy of Letters History and Antiquities

Hirata T (1996) Lead isotopic analyses of NIST standard reference materials using multiple collector inductively coupled plasma mass spectrometry coupled with a modified external correction method for mass discrimination effect. Analyst 121:1407-1411

Ingo GM, Angelini E, de Caro T, Bultrini G (2004) Combined use of surface and microanalytical techniques for the study of ancient coins. Appl Phys A Mater Sci Process 79(2):171-176

Jakimowicz R (1933) O pochodzeniu ozdób srebrnych znajdowanych w skarbach wczesnohistorycznych. Wiad Archeologiczne 12:103-136 
Jammer V (1952) Die Anfänge der Münzprägung im Herzogtum Sachsen, Hamburg

Kiersnowska T, Kiersnowski R (1955) Z dziejów obrotu kruszcowego w Polsce wczesnofeudalnej w swietle skarbu ze wsi Stojkowo, pow. Kolobrzeg Wiadomosci archeologiczne 22:5-54

Kolářová K, Děd J, Ottenwelter E (2014) Metallographical examination of silver jewellery from "Lumbe's garden" necropolis. Castrum Pragense 12(/2):289-310

Kostrzewski J (1962) O pochodzeniu ozdób srebrnych w polskich skarbów wczesnośredniowiecznych. Slavia Antiqua 9:139-211

Kulczycki P (2005) Estymatory jądrowe w analizie systematycznej. WNT, Warsaw

Linke R, Schreiner M (2000) Energy dispersive X-ray fluorescence analysis and X-ray microanalysis of medieval silver coins. Mikrochim Acta 133:165-170

Linke R, Schreiner M, Demortier G, Alram M (2003) The determination of the provenance of medieval silver coins: potentials and limitations of X-ray analysis using photons, electrons or protons. X-Ray Spectrom 32:373-380

Linke R, Schreiner M, Demortier G (2004) The application of photon, electron and proton induced X-ray analysis for the identification and characterization of medieval silver coins. Nuc Inst Methods Phys Res B 226:172-178

Liu SR, Chen KL, Rehren Th, Mei JJ, Chen JL, Liu Y, Killick D (2018) Lead isotope and metal source of Shang bronzes: a response to Sun et al.'s comments. Archaeometry In print. https://doi.org/10.1111/ $\operatorname{arcm} .12411$

Macháček J, Dresler P, Přichystalová R, Sládek V (2016) Břeclav Pohansko VII. Kostelní pohřebiště na Severovýchodním předhradí. Masarykova univerzita, Brno

Maczka M, Stysz M (2008) Kopalnia "Reiche Silber Gluck" w Dębowinie - relikt dawnego górnictwa antymonu w Górach Bardzkich. In: Dzieje górnictwa - element europejskiego dziedzictwa kultury, PP Zagożdżona i M. Madziarz (ed) Wrocław, p 213-226

Merkel SW (2016) Silver and the silver economy at Hedeby. Bochum. ISBN: 978-3-86757-017-6

Merkel S, Bräutigam B, Klein S, Hauptmann A (2013) The analysis of slag from the Panjhır mining region, Afghanistan: an investigation of (medieval) silver production technology [in]: Archäologishe Mitteilungenaus Iran und Turan, pp 231-250, Berlin

Miśta EA, Diduszko R, Gójska AM, Kontny B, Łozinko A, Oleszak D, Żabiński G (2017) Material description of a unique relief fibula from Poland. Archaeol Anthropol Sci. https://doi.org/10.1007/s12520017-0576-4

Munoz M, Baron S, Boucher A, Béziat D, Salvi S (2015) Mesozoic veintype $\mathrm{Pb}-\mathrm{Zn}$ mineralization in the Pyrenees: lead isotopic and fluid inclusion evidence from the Les Argentières and Lacore deposits. C.R. Geoscience. https://doi.org/10.1016/j.crte.2015.07.001

Ogden J (1982) Jewellery of the ancient world. Trefoil Books

Ontalba Salamanca MA, Demortier G, Fernandez Gomez F, Coquay P, Lavalcaba-Sil JL, Respaldiza MA (1998) PIXE and SEM studies of Tartesic gold artefacts. Nuc Inst Methods Phys Res B136-138:851857

Ottenwelter E, Děd J, Barčáková L (2014) Technical study of jewellery from the "Lumbe Garden" cemetery at Prague Castle. [in:] Frolík J ed.: Pohřebiště v Lumbeho zahradě na Pražském hradě. Díl II.
Studie. In: Castrum Pragense, vol 12. Archeologický ústav AV ČR, Praha, v.v.i., Praha, pp 163-287

Pliny E (1929) Metals: mostly gold, silver and mercury. In: Pliny the Elder: the Natural History, Book 33 chap, vol 25, p 29

Scrivano S, Gómez-Tubio B, Ortega-Feliu I, Ager FJ, Moreno-Suárez AI, Respaldiza MA, De la Bandera ML, Marmolejo A (2013) Identification of soldering and welding process in ancient gold jewellery by micro-XRF spectroscopy. X-Ray Spectrom 42:251-255

Scrivano S, Gómez-Tubio B, Ortega-Feliu I, Ager FJ, Paul A, Respaldiza MA (2017a) Compositional and microstructural study of joining methods in archaeological gold objects. X-Ray Spectrom 46:123130. https://doi.org/10.1002/xrs.2738

Scrivano S, Ortega-Feliu I, Gómez-Tubio B, Ager FJ, De la Bandera ML, Respaldiza MA, Ontalba-Salamanca MA (2017b) Non-destructive micro-analytical system for the study of the manufacturing processes of the group of gold jewels from "El Carambolo" treasure. Rad Phys Chem 130:133-141

Ślesiński W (1995) Konserwacja zabytków sztuki. Rzemiosło artystyczne, Warsaw

Šmit Ž, Šemrov A (2006) Early medieval coinage in the territory of Slovenia. Nucl Inst Methods Phys Res B 252:290-298

Šmit Ž, Budnar M, Pelicon P, Zorko B, Knific T, Istenič J, Trampuž-Orel N, Demortier G (2000) Analyses of gold artefacts from Slovenia, Nuc. Inst. And Meth. In: Physics Research B 166-163, pp 753-757

Stos-Gale ZA, Gale NH (2009) Metal provenancing using isotopes and the Oxford archaeological lead isotope database (OXALID). Archaeol Anthropol Sci 1:195-213

Suchodolski S (1971) Początki mennictwa w Europie Środkowej, Wschodniej i Północnej. Wrocław

Tamla Ü (2016) Bracteate pendant from the Linnakse hoard: archaeometric discussion of the silver artefact. Estonian J Archaeol 20(2):150-164. https://doi.org/10.3176/arch.2016.2.03

Theophilus (1979) On divers arts. Translated by Hawthorne JG and Smith CS

Thouvenin A (1971) La Fabrication des Fils et des Filigranes de Métaux Précieux chez les Anciens. Rev Hist Mines et de la Métallurgie 3: 89-108

Thouvenin A (1973) La soudure dans la construction des uevres d'orfevrerie antique et ancienne, Revue archéologique de l'Est et du Centre-Est (Dijon), XXIV no 91, fasc 1:11-68

Tuah-Poku I, Dollar M, Massalski BT (1988) A study of the transient liquid phase bonding process applied to the $\mathrm{Ag} / \mathrm{Cu} / \mathrm{Ag}$ sandwich joint. Metall Mater Trans A 19(3):675-686

Untracht O (1985) Jewellery. Concepts and technology. Doubleday, New York

Wolters JZ (1978) Geschichte der Löttechnik, Degussa Frankfurt, Germany

Wolters J (1983) Die Granulation. Geschichte und Technik einer alten Goldschmiedekunst. Callwey Verlag, Munich

Zoll-Adamikowa H, Dekówna M, Nosek EM (1999) The Early Mediaeval hoard from Zawada Lanckorońska (Upper Vistula River), Warszawa

Publisher's note Springer Nature remains neutral with regard to jurisdictional claims in published maps and institutional affiliations. 